\title{
Guidelines for Hanford Site Implementation of the National Environmental Policy Act
}

S. E. King

March 1989

Prepared for the U.S. Department of Energy under Contract DE-AC06-76RLO 1830

Pacific Northwest Laboratory Operated for the U.S. Department of Energy by Battelle Memorial Institute 


\title{
DISCLAIMER
}

This report was prepared as an account of work sponsored by an agency of the United States Government. Neither the United States Government nor any agency thereof, nor Battelle Memorial Institute, nor any or their employees, makes any warranty, expressed or implied, or assumes any legal liability or responsibitity for the accuracy, completeness, or usefulness of any information, apparatus, product, or process disclosed, or represents that its use would not infringe privately owned rights. Reference herein to any specific commercial product, process, or service by trade name, trademark, manutacturer, or otherwise does not necessarily constifute or imply its endorsement, recommendation, or favoring by the United States Government or any agency thereof, or Battelle Memorial Institute. The views and opinions of authors expressed herein do not necessarily state or reflect those of the United States Government or any agency thereot.

\author{
PACIFIC NORTHWEST LABORATORY \\ operated by \\ BATTELLE MEMORIAL INSTITUTE \\ for the \\ UNITED STATES DEPARTMENT OF ENERGY \\ under Contract DE-AC06-76RLO 1830
}

\author{
Printed an the United States of America \\ Available trom \\ National Technical Information Serve \\ United state Department of Commerce \\ 5285 Purt Royal Road \\ springfiteld, Virgina 2216 i \\ NTIS Price Codes \\ Microfiche A01 \\ Printed Copy
}

$\begin{array}{cc}\text { Pages } & \begin{array}{c}\text { Price } \\ \text { Codes } \\ \text { 1007-025 }\end{array} \\ 026-050 & \text { A02 } \\ 051-075 & \text { A03 } \\ 076-1100 & \text { A04 } \\ 101.125 & \text { A05 } \\ 126.150 & \text { AO6 } \\ 151-175 & \text { A07 } \\ 176-200 & \text { A06 } \\ 201-225 & \text { A09 } \\ 226-250 & \text { A10 } \\ 251.275 & \text { A11 } \\ 276-300 & \text { A12 } \\ & \text { A. } 3\end{array}$


PNL -6755

UC -630

GUIDELINES FOR HANFORD SITE

IMPLEMENTATION OF THE NATIONAL

ENVIRONMENTAL POLICY ACT

S. E. King

March 1989

Prepared for

the U.S. Department of Energy

under Contract DE-ACO6-76RLO 1830

Pacific Northwest Laboratory

Richland, Washington 99352 


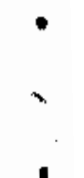




\section{FOREWORD}

This report has been prepared in support of the environmental policy of the U.S. Department of Energy (DOE), as set forth in DOE Directive DOE N5400.3, "Environmental Policy Statement." (a) This order states that it is DOE's policy to conduct its activities in an environmentaliy safe and sound manner. Further, it is also the policy of DOE to conduct its operations in accordance with the letter and spirit of applicable environmental statutes, regulations and standards. The subject of this report, the National Environmental Policy Act (NEPA), is one of the applicable federal environmental statutes for Hanford Site activities.

(a) The directive expired July 1, 1988; however, a DOE headquarters message states that the policy remains in effect until a replacement is issued. 


\section{$\bullet$}

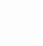

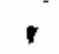

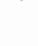




\section{SUMMARY}

The National Environmental Policy Act (NEPA) environmental review process is mandatory for federal agencies. Understanding and complying with NEPA is extremely important to successfully planning and implementing programs at the Hanford Site. This report, which was prepared by Pacific Northwest Laboratory (PNL), is intended to help planners and decision makers understand NEPA by describing the NEPA process as it is outlined in NEPA, in regulations, and in guidance information. The requirements and guidance documents that set forth the NEPA process are discussed as well. Some of the major NEPA concepts and issues are also addressed.

This report is intended to be used as a general road map through the maze of NEPA requirements and guidance to ensure that Hanford Site activities are conducted in compliance with NEPA. Enhanced knowledge of the NEPA process is expected to increase the ability of the Hanford Site to work with regulators, interested parties and the public to ensure that the potential environmental impacts of DOE activities are fully considered at the Hanford Site. In addition, an enhanced understanding of NEPA will help project and program managers to integrate NEPA compliance requirements with program planning. NEPA compliance early in project planning and throughout a project's life ensures consideration of environmental concerns, minimizes the chance for project deiay and premature commitment of resources, avoids prejudicing the NEPA review process, and facilitates acquisition of environmental permits. 


\section{$\bullet$}

1 


\section{CONTENTS}

FOREWORD ............................ i i

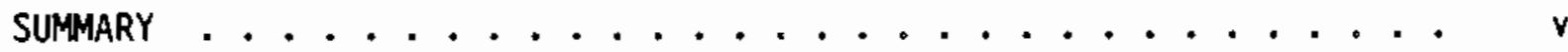

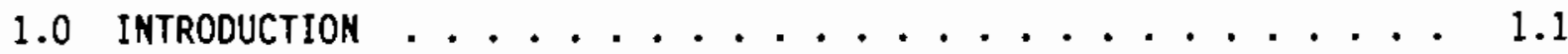

1.1 NEED . . . . . . . . . . . . . 1.2

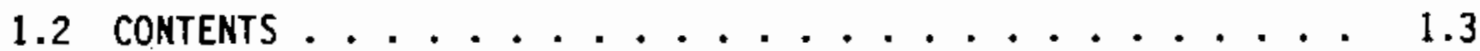

2.0 THE NEPA COMPLIANCE PROCESS AT THE HANFORD SITE $\ldots \ldots \ldots$

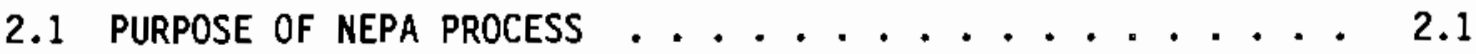

2.2 APPLICABILITY OF PROCESS TO FEDERAL ACTIVITIES . . . . . 2.2

2.3 REQUIREMENTS AND GUIDANCE $\ldots \ldots \ldots \ldots$

2.3.1 The National Environmental Policy Act ....... 2.5

2.3.2 Council on Environmental Quality Regulations and Guidance ................... 2.5

2.3.3 DOE Regulations and Guidance ......... 2.5

2.3 .4 Case Law . . . . . . . . . . . . 2.7

2.4 PROCESS .............................. 2.10

2.4.1 Step 1: Identify the Proposed Action ....... 2.10

2.4.2 Step 2: Gather Data to Address the Threshoid

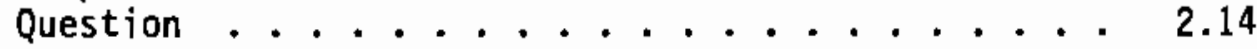

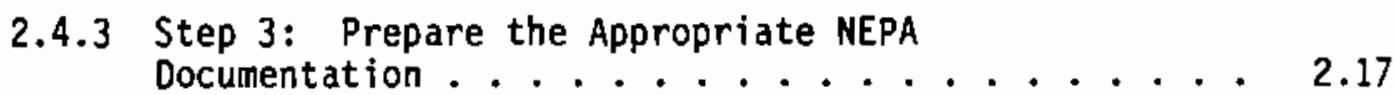

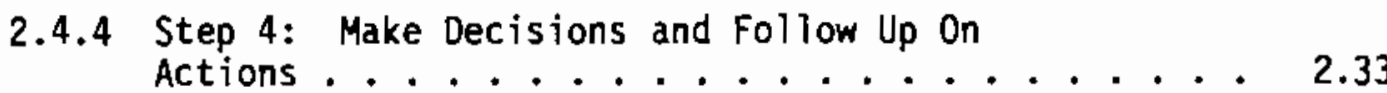

3.0 NEPA IMPLEMENTATION 1SSUES IMPORTANT TO THE HANFORD SITE $\ldots \ldots$

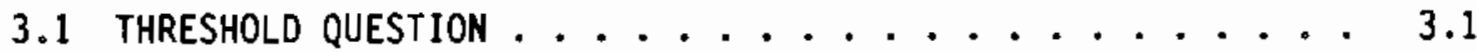

3.2 Programmatic and SuPPlemental EISs . . . . . . . 3.2 
3.3 OTHER ENVIRONMENTAL REQUIREMENTS . . . . . . . 3.6

3.4 HORST-CASE ANALYSIS . . . . . . . . . . 3.10

3.5 Mitigation . . . . . . . . . . . . . . 3.12

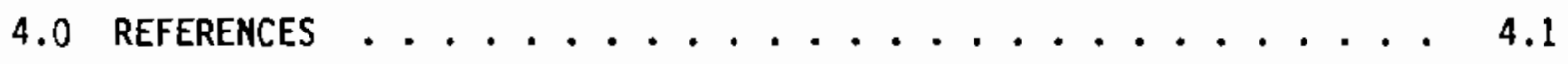

APPENDIX A - THE LOCATIONS OF MAJOR NEPA CONCEPTS IN

REQUIREMENTS AND GUIDANCE DOCUMENTS .......... A.1

APPENDIX B - DOE NEPA GUIDELINES, 52 FR 47663, DECEMBER 15, 1987 . . B. B

APPENDIX C - ENVIRONMENTAL EVALUATION CHECKLIST FROM RL

ORDER $5440.1 \mathrm{~A} \ldots \ldots \ldots \ldots \ldots \ldots . \ldots \ldots$

APPENDIX D - ENVIROMMENTAL CHECKLIST FROM THE STATE

ENVIRONMENTAL POLICY ACT REGULATIONS . . . . . . D. 


\section{FIGURES}

1.1 Section 102(2)(C) of NEPA ....................... 1.3

2.1 Relationship of NEPA Statute, Regulations, Guidance, and

Case Law ....................... 2.4

2.2 Table of Contents of CEQ Regulations . . . . . . . 2.6

2.3 A Listing of Inadequacies of EISs ............ 2.9

2.4 Flowchart of the Major Steps of the NEPA Process . . . . . 2.11

3.1 CEQ's Regulatory Definition of "Significantly" as Used in Section $102(2)(C)$ of NEPA ........................ 3

\section{TABLES}

2.1 Number of NEPA Cases and Resulting Injunctions Against Federal Agencies from 1979 through 1985 . . . . . . . 2.8

3.1 0ther Federal Environmental Statutes and Executive Orders Applicable or Potentially Applicable to DOE Activities at Hanford . . . . . . . . . . . . . . . . . 3.7

3.2 Federal, State, and Local Agencies Responsible for Implementation of Selected Federal Environmental Statutes, Regulations and Executive Orders . . . . . . . 3.9 


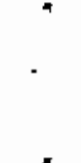




\subsection{INTRODUCTION}

The National Environmental Policy Act (NEPA) of 1969 was enacted by Congress as "our basic national charter for protection of the environment" (CEQ 1978). Its purpose is to set forth a national policy to make thorough consideration of environmental impacts a routine part of the operations planning of federal agencies (CEQ 1980) before such activities are undertaken. NEPA's implementing regulations provide a process which federal agencies such as DOE must follow to comply with its legal requirements. Compliance with these procedural aspects of NEPA throughout the life of a project reduces the risk of project or program delay, as well as of litigation; and ensures regulators, legislators, interested parties and the public that environmental considerations are being addressed adequately at federal facilities. In addition, NEPA is intended to be used as a vital and integral part of the decision-making process for federal agencies (Bear 1988).

This report gives a broad overview of NEPA and the associated environmental review process as it applies to projects/programs at the Hanford Site. The intent of the report is to provide a description of the DOE NEPA process, its documentation, and some of its concepts and issues. To give the reader greater understanding of NEPA, this report

- identifies the regulations and guidance that govern implementation of NEPA at the Hanford Site

- describes the step-by-step process for complying with the procedural aspects of NEPA

- provides information on the content of NEPA documentation that must be prepared with respect to Hanford programs and projects

- identifies major NEPA concepts and issues that typically arise during implementation of the NEPA process. 


\subsection{NEED}

NEPA provides a means by which federal agencies can systematically consider the environmental effects of their actions in strategic planning. It is as important today as it was almost 20 years ago, when first enacted. NEPA compliance does not require that environmental concerns be placed above all other agency considerations, such as agency mission or economic, technical, and political factors; it does require that the agencies be fully cognizant of these environmental concerns in their decision making. The primary means by which federal agencies meet these goals is by following the "action-forcing" provisions of NEPA's Section 102(2)(C) (see Figure 1.1).

Since NEPA was enacted by Congress in 1969, a considerable body of information including regulations, guidelines, court cases, and literature has been developed that helps federal agencies understand and implement NEPA. These numerous resources have varying purposes, degrees of detail and coverage. The plethora of information can sometimes be confusing to the person responsible for implementing NEPA in the field, as well as for managers and policymakers not familiar with NEPA. Some of this confusion arises from the vagueness of the statute; its statutory terms are not precise. This report strives to make MEPA implementation clearer to program and project managers at the Hanford Site by integrating and sumarizing the various requirements and guidance available.

This report will provide a roadmap through the maze of requirements and guidance for Hanford Site employees to use to ensure that they are conducting their activities in compliance with NEPA. NEPA compliance early in project/program planning and throughout a project's life has a number of benefits, including the following:

- ensures consideration of environmental concerns

- minimizes the chance for construction delay and premature commitment of resources

- avoids prejudicing the NEPA review process

- facilitates acquisition of any required environmental permits. 
From HEPA, Section 102(2)(C):

"... all agencies of the Federal Government shall-...

(C) include in every recomendation or report on proposals for legislation and other major Federal actions significantly affecting the quality of the human environment, a detailed statement by the responsible official on-

(i) the environaental impact of the proposed action,

(ii) any adverse environmental effects which cannot be avoided should the proposal be inipleanented.

(iii) alternatives to the proposed action.

(iv) the relationship between local short-tera uses of man's environment and the maintenance and enhancenent of long-tera productivity, and

(v) any irreversible and irretrievable coniaitments of resources which would be involved in the proposed action should it be implenented.

Prior to making any detailed statement, the responsible Federal official shall consult with and obtain the coments of any Federal agency which has jurisdiction by law or special expertise with respect to the environmental impact involved... ."

FIGURE 1.1. Section 102(2)(C) of NEPA

\subsection{CONTENTS}

This report is a general outline of the requirements of NEPA as they are presented in the statute, in the Council on Environmental Quality (CEQ) regulations and guidance, and in DOE Headquarters and DOE Richland Operations office guidance and administrative orders. A step-by-step analysis of the 
NEPA process is presented. In addition, the report provides discussions of current NEPA compliance concepts and issues that could be relevant to the Hanford Site.

This report is not a substitute for any of the NEPA requirement and guidance documents discussed in Section 2.3; rather, this report is intended to assist in understanding the content of these documents and how to use them more readily. 


\subsection{THE NEPA COMPLIANCE PROCESS AT THE HANFORD SITE}

The NEPA compliance process for the Hanford Site consists of a series of procedura1 steps to ensure compliance with Section 102(2)(C) of NEPA: identifying the activity to be undertaken, determining the level of NEPA documentation required, preparing the NEPA documentation, deciding whether or how to proceed with the activity, and following up on that decision. This chapter a] so provides some detail as to the type of information to be included in each NEPA and DOE supporting document.

This chapter deals with environmental review of programs, projects and activities because these are the types of NEPA review applicable to Hanford Site activities. This environmental review process addresses only the procedural provisions of Section 102(2)(C) of NEPA. The chapter does not discuss the environmental review process as it applies to legislation or federal rulemaking. Neither does it address compliance with the substantive environmental protection policy and goals that are contained in Sections 101, 102(1), 103, 104, and 105 of NEPA. These sections deciare a national environmental policy; require federal agencies to use a systematic, interdisciplinary approach to planning and decision making; direct federal agencies to conform their administrative procedures to national environmental policy; recognize obligations of federal agencies to comply with environmental quality standards, coordinate with other agencies, and act independently; and provide that this Act supplements existing federal agency authorizations.

In the report sections that follow, the purpose and applicability of the NEPA environmental review process are discussed. Then a description of the NEPA compliance requirements and guidance from various documents is presented. Finally, the NEPA process as presented in these requirements and guidance documents is provided.

\subsection{PURPOSE OF NEPA PROCESS}

According to regulations promulgated by the CEQ, the NEPA process is intended to help public officials make decisions that are based on an 
understanding of environmental consequences, and to take actions that protect, restore and enhance the environment.

\subsection{APPLICABILITY OF PROCESS TO FEDERAL ACTIVITIES}

The NEPA environmental review process is mandatory for federal agencies and is applicable to review of all their proposed actions and the subsequent decisions they make (CEQ 1980). (The NEPA process also applies to activities undertaken by $\mathrm{DOE}$ contractors on behalf of $\mathrm{DOE}$, but the responsibility for NEPA compliance rests with DOE.) As stated by the court in the case Calvert Cliffs' Coord. Comm. v. Atomic Energy Commission (1971, 1972), "Compliance to the 'fullest' possible extent would seem to demand that environmental issues be considered at every important stage in the decision-making process concerning a particular action--at every stage where an overall balancing of environmental and non-environmental factors is appropriate and where alterations might be made in the proposed action to minimize environmental costs" (Rogers 1977).

\subsection{REQUIREMENTS AND GUIDANCE}

This section introduces the various requirements and guidance applicable to NEPA compliance at the Hanford Site. Knowledge of the existence of this material and its basic content is important because the reader may need to refer to these materials, since this report cannot provide all the details contained in these regulations and guidance. Familiarity with the NEPA statute and its implementing regulations is particularly important, since these are the legal bases for court action. As stated by Bear (1988), Congress, the CEQ, and the judiciary provide strong oversight and enforcement functions. The material in this section forms the background for understanding the discussion of the NEPA process in Section 2.4.

NEPA compliance at the Hanford Site is governed by the following:

- NEPA statute

- CEQ regulations [40 CFR 1500-1508 (CEQ 1986b)] and related CEQ guidance 
- DOE regulations [10 CFR 1021 (DOE 1988a)] and DOE NEPA Guidelines (DOE 1987)

- DOE Order 5440.1C (DOE 1985) and RL Order 5440.1A (DOE-RL 1987)

- DOE/EV-0132, DOE Environmental Compliance Guide

- DOE memoranda

- case law.

Figure 2.1 depicts these regulations and guidance and their relation to one another. Also discussed as guidance for NEPA compliance is case law, for it is an integral part of understanding how NEPA is applied and interpreted by the courts. Case law helps to further define those unclear, undefined, or controversial aspects of NEPA.

As a useful aid in locating the discussion of specific NEPA documentation and concepts within each of these requirement or guidance documents, a matrix has been provided in Appendix $A$. This matrix is particularly useful as a reference for all pertinent discussions of major NEPA concepts and documentation in the requirements and guidance documents discussed in Section 2.3 of this report. The matrix will save time in answering specific NEPA questions that program and project managers may have.

Because the nature of environmental regulatory compliance is an everchanging one, it is important that in determining NEPA compliance requirements for Hanford activities, DOE-RL and its contractors track the evolution of the NEPA regulatory framework, NEPA guidance, and litigation trends. This tracking can be accomplished through periodic review of the Federal Register; subscription to environmental compliance services such as the Environmental Law Reporter; attendance at classes, conferences and courses discussing the latest NEPA trends; interfaces with DOE Headquarters' Office of NEPA Project Assistance; tracking of past and pending NEPA litigation; and consultation with the RL Office of Chief Counsel.

The sections below describe the various NEPA requirements and guidance documents that must be addressed in Hanford Site compliance, beginning with a discussion of NEPA itself. 


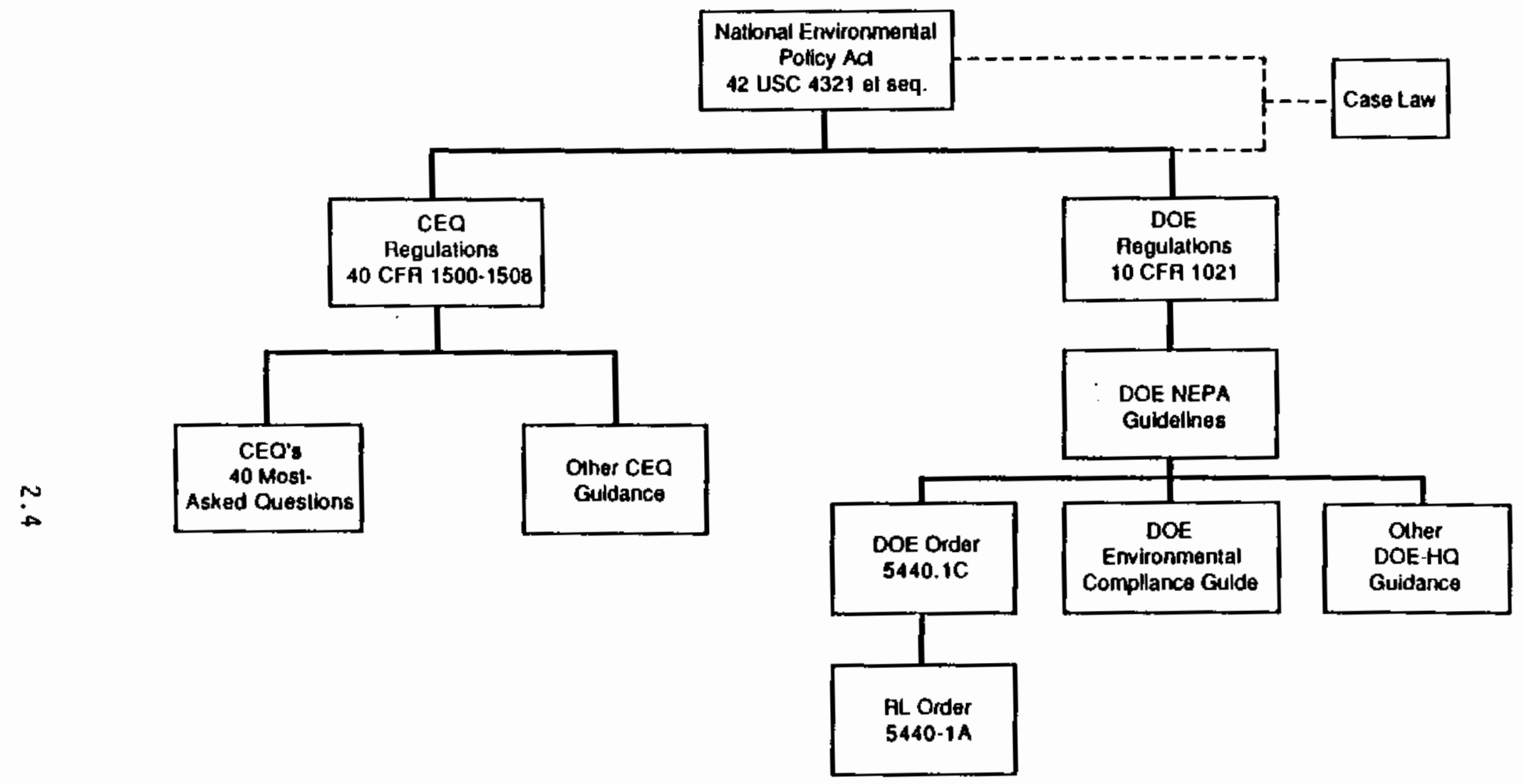

FIGURE 2.1. Relationship of NEPA Statute, Regulations, Guidance, and Case Law 


\subsubsection{The National Environmental Policy Act}

The National Environmental Policy Act of 1969 was enacted by Congress as Public Law 91-190 and is "our basic national charter for protection of the environment" (CEQ 1978). It can be found in the U. $\dot{S}$. Code Annotated in 42 USCA 4321 et seq. The purpose of NEPA is to set forth a national policy to encourage harmony between people and their environment, to promote efforts to prevent or eliminate environmental damage and stimulate human health and welfare, to enrich the understanding of our ecological systems and natural resources, and to establish a Council on Environmental Quality.

Federal agencies are most familiar with Section 102(2) of NEPA, which gives the procedurat requirements, or "action-forcing provisions," that federal agencies must follow to comply with NEPA (see Figure 1.1). These action-forcing provisions are emphasized in this report.

\subsubsection{Council on Environmental Qual ity Regulations and Guidance}

The CEQ has been authorized to promulgate regulations for federal implementation of NEPA and has provided various guidance as well. The CEQ regulations in Title 40 of the Code of Federal Regulations, Sections 1500-1508, are applicable to federal agencies and provide procedures with which federal agencies are legaliy bound to comply. These regulations are also applicable to contractor projects funded by DOE. An outline of the sections of the CEQ regulations is provided in Figure 2.2.

Other CEQ guidance includes a CEQ memorandum to federal agency officials that provides answers to the "40 most-asked questions" concerning the CEQ's implementing regulations; the memo was published in the Eederal Register on March 23, 1981 [46 FR 18026-18038 (CEQ 1981b)]. In addition, CEQ provided guidance regarding NEPA regulations in the July 28, 1983, Federal Register [48 FR 34263 (CEQ 1983a)]. These are examples of the kind of useful guidance available from the CEQ. The specific topics discussed in this guidance are provided in the matrix in Appendix A.

\subsubsection{DOE Regulations and Guidance}

Council on Environmental Quality regulation 40 CFR 1507.3 requires federal agencies to adopt their own procedures to supplement the CEQ 


\section{TABLE OF CONTENTS

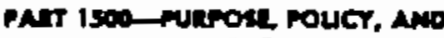 maroate}

Ser

1500.1 Furpoce

1500.2 Polley.

1500.3 Mindite.

1500.4 Reductas peperwort.

1500.5 Reduetns deley.

1500.8 Arepcy authority.

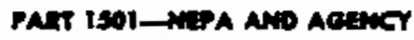
rupinita

IS01.1 Purpase

1501 A Apoly NixPA erly in the proted

1301.3 Wher to proparte an environmert tel entermete

1501.4 Whether to prepert an eortronmontel impoet strement.

15015 tond agentel.

1501. Cooperatint remeite.

150L.7 scopine.

180Ls The llimitn

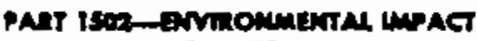
STA THET

15021 Purpane.

1502 Implerwentedon.

IB02 2 Btaritory requitremente for stacer merate

1502. Mislor Fodarl settom roputring the properitston of entronmentel

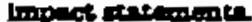

15025 Tinin:

18026 Interdipolpling preparion

15027 Far llmite

15028 Writing

10029 Drets find and supplementer intratiegth

150210 Recommendod forant.

1sazdl Cover ineot

150217 Swmming.

1502.13 Finpore and need.

W02.14 Alteraidios betuding the pro poied extron.

itan is Affected emtromment

I50210 Intronmental consequences.

190217 Lite of pireprets.

LS02.18 Appoadtex

1302 Is Circulation of the entronmeninf Inpet starement.

190230 Thertar

150231 Incoroortion by reference.

rov22 incomplete or unnvilinble inforiniog

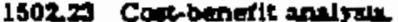

1502.24 Methodolosy and sciertifle acturesy.

1502,25 Entronmental revien and consulbasion reauirements.

Fan 1502 coninginno

1303.1 invitint commente.

1503.2 Duty to comment.

1503.3 Specifleity of commenes.

1503.4 Respunis to chatrents.

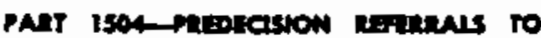

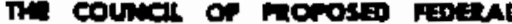

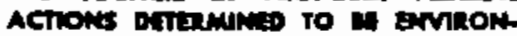

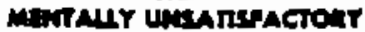

I504I Purpace

15042 Gitere for tefertal

15043 Procedure for refermin and re10000.

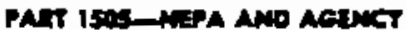

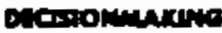

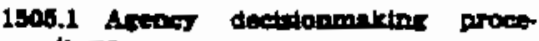
dure-

15042 Record of dectrion in eanes re

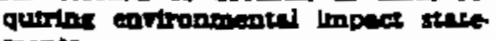
mente.

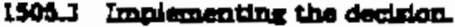

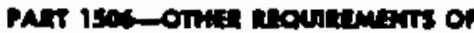
In:

1504.1 Insitatione an ectlom durins NiPA Drocere

13003 Fitmination of dupllewedon fitr State and locil procenturen

1508.3 Adoption.

1504.4 Combintas documente.

Isoas Agency responsibility.

1504. Fubile lovolvetnent.

15027 Firther gitdance

150.4 Provonit for leditintlon.

18049 filing retutrements.

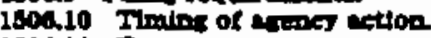

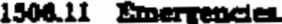

130d12 motertive duse.

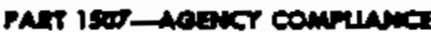

Isorit Camplinote.

1901.1 Areas anablity to comply.

18 tr.3 Aroag precedurt.

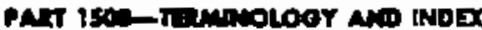

1508.1 Terminolory.

1508.2 Act.

1502.3 Affecting.

150.4 Cateiorted excluston.

1508.5 Coopereting enency.

I508.9 Council.

1508.7 Cumulative impact.

1508.8 Effects.

1508.9 invironmental asseswent.

1509.10 Entronmentol document.

1508.11 Bevirontmental tmpact statement.

1508.12 Federal agency.

$1 \$ 08.13$ Findint of no significant impact.

1508.14 Humn environment.

$150 a .15$ Juridiction by in:

isolis Leid arency.

150.17 Ledallion.

1508.18 M-jor Federd action.

1508.19 Mrtter.

150 a20 Mulotion.

160.21 NIPAA proces.

$150 \mathrm{z}$ Notlec of intent

1508.24 Proposil

1508.24 Referting actincy.

Isod.25 seope.

1506.28 Spectal expertise.

1508.27 Simlificandy.

1508.28 Thering.

FIGURE 2.2. Table of Contents of CEQ Regulations 
regulations. In 10 CFR 1021, DOE formally adopted the CEQ regulations for implementing Section 102(2) of NEPA. DOE then published final guidelines in the Federal Register providing DOE's implementation of the CEQ requirements (see Appendix B). The most current, amended version of the guidelines appears in 52 FR 47663 (DOE 1987).

The Department of Energy also issued DOE Order 5440.1C. "Implementation of the National Environmental Policy ACt" (DOE 1985). (A DOE order is a type of agency directive that establishes agency policies, standards or procedures.) This order established DOE's policy to comply fully with the spirit and letter of NEPA. The order delineates responsibilities for implementing NEPA and delegates authority to various DOE officials and organizations. The main responsibilities of these entities are to coordinate NEPA documentation, provide technical assistance, and review NEPA documentation.

The Richland Operations Office of DOE has issued RL Order 5440.1A, "Implementation of the National Environmental Policy Act at the Richland Operations Office" (DOE-RL 1987). The Order states that it is the policy of RL to fully comply with the spirit and letter of NEPA, to promote protection of environmental quality, and to ensure the health and safety of the public.

DOE implementation of NEPA is also guided by its Environmental Compliance Guide (OOE/EV-0132) (DOE 1981), as amended, which includes an overall scheme for environmental compliance planning. Appendix $A$ of the Guide contains format and content requirements for all NEPA and DOE supporting documentation, as well as guidance for NEPA procedures such as circulating EISs and preparing for public hearings. In addition, a NEPA Compliance Guide is being prepared for DOE's Office of NEPA Project Assistance and will contain an update of the 1981 guidance.

Additiona1 NEPA guidance is provided from time to time by DOE Headquarters' Office of NEPA Project Assistance, which is under the Assistant Secretary for Environment, Safety and Health (EH).

\subsubsection{Case Law}

NEPA case law is an integral part of understanding the actions required for NEPA compliance. Tracking of NEPA litigation is an important part of a 
NEPA compliance program, for even a single case interprets the law and may set a precedent. Many court rulings in essence "build" and further define the law.

In fact. MEPA's substantial effect on federal agency decision making has primarily been due to the large number of lawsuits it has spawned. NEPA interpretation by the courts has helped to give form to its general provisions (Vanderver and Martin 1987).

The following statistics provide an idea as to how powerful a force NEPA litigation has been in federal agency decision making. The CEQ (1978) reports that from MEPA's inception in 1970 to December 31, 1977, 938 NEPA cases had been filed against the federal agencies it surveyed. In about $35 \%$ of these cases, the courts acted by producing injunctions that delayed projects. As an example, the numbers of cases brought against federal agencies from 1979 through 1985 (CEQ 1980, 1981a, 1982, 1983b, 1985; Bear 1988) are provided in Table 2.1.

In the 139 cases filed against federal agencies in 1979, 61: were because an agency failed to prepare an EIS, 25\% were because the EIS was

IABLE 2.1. Number of NEPA Cases and Resulting Injunctions Against Federal Agencies from 1979 through 1985

\begin{tabular}{ccc}
$\frac{\text { Year }}{1979}$ & $\begin{array}{c}\text { Number } \\
\text { of Cases }\end{array}$ & $\begin{array}{c}\text { Number of } \\
\text { Injunctions }\end{array}$ \\
\cline { 2 - 3 } 1980 & 139 & 12 \\
1981 & 140 & 17 \\
1982 & 114 & 12 \\
1983 & 157 & 19 \\
1984 & 143 & 21 \\
1985 & 89 & 14 \\
& 77 & 8
\end{tabular}


inadequate (see Figure 2.3), and $14 \%$ were for other reasons. In 1985, the issue of cumulative impacts was particularly significant in case law (CEQ 1986a).

Regarding the timing of lawsuits brought under NEPA, the CEQ's intention is that judicial review of agency compliance with the regulations not occur before the final EIS has been filed or before the agency has made a finding of no significant impact (FONSI) (40 CFR 1500.3). The regulations further state the CEQ intends that any trivial violation of the regulations not give rise to an independent "cause of action," a situation that would give a party the right to sue (Black 1983).

The CEQ plans to explore alternative dispute resolution (ADR) as a means of avoiding traditional litigation (Bear 1988), which can be lengthy, costly, and which may not necessarily satisfy the goals of the parties involved. Alternative dispute resolution is a voluntary approach directly involving the parties in seeking resolution without employing litigation (MacDonnell 1988).

"Fatally defective" EISs, as Tisted by Vanderver and Martin (1987):

- sweeping conclusions unsupported by facts

- vagueness as to important issues

- internal contradiction

- disregard for local land use planning requirenents

- cursory treatment of secondary and cumulative environment iupacts

- failure to include sufficient information on the environmental impact of realistic and plausible alternatives

- failure to wake an unbiased comparison of alternatives with proposed action

FIGURE 2.3. A Listing of Inadequacies of EISs 


\subsection{PROCESS}

This section discusses the major steps of the NEPA environmental review process as they appear in the CEQ regulations and guidance. A detailed flowchart of the NEPA environmental review process is shown in Figure 2.4 (partially derived from DOE 1981).

The process essentially consists of four main activities:

1. Identify the proposed action

2. Gather data to address the "threshold" question, "Will this be a major federal action significantly affecting the quality of the human environment?"

3. Prepare appropriate NEPA documentation according to the following:

a. If the answer to Question 2 is "yes," prepare an environmental impact statement.

b. If the answer to Question 2 is "no," prepare no NEPA documentation.

c. If Question 2 cannot be answered based on the information available, prepare an environmental assessment to gather more information and enable Question 2 to be answered either affirmatively or negatively.

4. Make decisions and follow up.

The NEPA compliance process under these four steps is outlined betow.

\subsubsection{Step 1: Identify the Proposed Action}

Before the appropriate level of MEPA documentation can be determined, it is important that the "proposed action" be identified fully and scoped adequately. Some of the pertinent questions to be answered for identification of the action's scope are these: Is it the first part of a long-tern program, or are its beginning and end points clearly defined? Is it a series of minor actions whose cumulative effects could have a major environmental impact and thus require an EIS? Is it a policy, a program, or a project? 


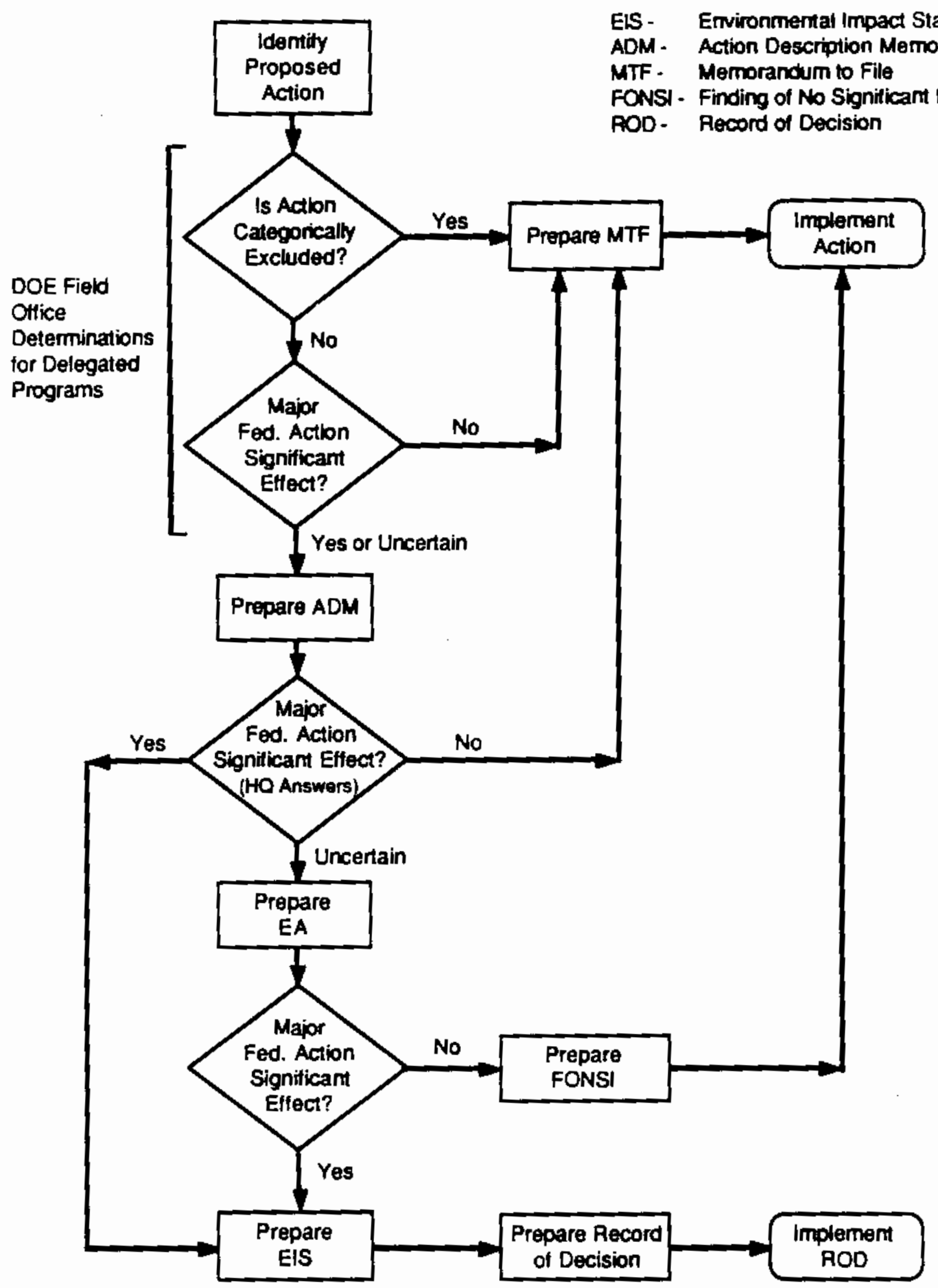

FIGURE 2.4. Flowchart of the Major Steps in the NEPA Process 
The answers to these questions have a bearing on the type (i.e., programmatic or project-specific EIS--see Chapter 3) and content of NEPA documentation required by a particular activity.

Actions under NEPA are defined in 40 CFR 1508.18 to include the following:

- new and continuing activities, including projects and programs entirely or partiy financed, assisted, conducted, regulated, or approved by federal agencies

- new or revised agency rules, regulations, plans, policies, or procedures

- legislative proposals.

40 CFR 1508.18 continues by stating that these actions tend to fall within one of the following categories:

- adoption of formai plans, such as official documents prepared or approved by federal agencies which guide or prescribe alternative uses of federal resources, upon which future agency actions will be based

- adoption of programs, such as a group of concerted actions to implement a specific policy or plan; systematic and connected agency decisions allocating agency resources to implement a specific statutory program or executive directive

- approval of specific projects, such as construction or management activities located in a defined geographic area. Projects include actions approved by permit or other regulatory decision as well as federal and federally assisted activities.

Once the proposed action is fully understood, a preliminary step to determining the appropriate level of NEPA documentation is to compare the proposed action with the list of actions presented in Section $D$ of the DOE NEPA Guidelines (see Appendix B). Proposed actions can be found in one of the three categories of Section D: 
- actions that usualiy require an EIS

- actions that normally do not require either an EIS or an EA (categorical exclusions; see below)

- actions which normally require an EA but not necessarity an EIS.

A categorical exclusion is defined in the CEQ regulations as a category of actions that individualiy or cumulatively do not have a significant effect on the human environment, as defined by the agency in question. For these categories of proposed actions, neither an EA nor an EIS is required. However, an agency may still decide to prepare an environmental assessment "for extraordinary circumstances in which a normally excluded action may have a significant environmental effect" (CEQ 1978).

According to recent DOE guidance, ${ }^{(a)}$ a memorandum must also be prepared for the file when the proposed action falis under the DOE categorical exclusion (DOE 1987) of "actions that are substantially the same as other actions for which the environmental effects have already been assessed in a NEPA document and determined by DOE to be clearly insignificant and where such assessment is currently valid." The accompanying documentation is prepared to support the conclusion that the actions are substantially the same as the earlier NEPA document, the effects have been determined to be cleariy insignificant, and the assessment is still valid.

If the action falls into one of the three categories above, then the indicated document (if any) should generally be prepared. The only exceptions to this guidance are if DOE believes that the categorization is not appropriate to the proposed action, or if public comment received on or related to a proposed action within Section $D$ raises a question regarding the categorization (DOE 1987). In many instances, however, the proposed action does not neatly fit the defined actions in any of the three categories mentioned above. Therefore, the process then moves on to Step 2 (below), the

(a) U.S. Department of Energy. March 1988. "NEPA Guidance Related to Memorandums-to-File and Categorical Exclusions." 
review of individual proposed actions to determine the appropriate level of NEPA documentation (Section A.3 of "DOE NEPA Guidelines"; see Appendix B).

\subsubsection{Step 2: Gather Data to Address the Threshold Question}

Once DOE determines the scope and extent of the proposed action, it proceeds to the next step, gathering data on the potential environmental effects of the proposed action to determine whether it is a major federal action significantly affecting the quality of the human environment [from Section $1 D 2(2)(C)$ of the Act; hereafter referred to as the "threshold" question].

To answer the threshold question of whether its proposed action is major with significant environmental effects, DOE-RL utilizes several supporting documents as a vehicle for this information-gathering activity (see Chapter 3 for more information on the threshold question). These documents are being referred to as supporting documentation because they are not required by law (i.e., they are not required either by NEPA or the CEQ or DOE regulations), but instead are required by DOE internal policy. Supporting documents are a means by which DOE provides an adequate record of its decision-making process.

The first of these supporting documents is the environmental evaluation, or $\mathrm{EE}$, required for the Hanford site by $\mathrm{RL}$ Order 5440.1A (DOE-RL 1987). (The EE requirement appears only in RL 5440.1A and not in any other guidance discussed in this report.) The EE helps to determine the environmental effects of an activity and the significance of these effects.

The EE consists of text and a checklist. The EE checklist addresses the potential impacts to the environment as a result of carrying out the proposed action. The checklist is a way of consistently and methodically addressing the potential impacts to air, water, soil, other natural resources, cultural resources, 1and use, etc. (Appendix $C$ ). The text of the EE describes the action, provides its purpose, shows its location, provides the anticipated start and end dates and the estimated costs, and provides an explanation for any of the items marked "Yes" on the checklist. 
The anaiysis of the preliminary data presented in the EE regarding potential impacts should make clear those proposed actions for which the environmental effects are cleariy insignificant. For these actions, the only supporting documentation DOE requires is a memorandum to file (MTF).

The MTF was created by DOE for those clearly insignificant actions that have not yet been categorically exciuded in Section $D$ of the DOE NEPA Guidelines. As stated in a 1981 memo from the Assistant Secretary for Environmental Protection, Safety, and Emergency Preparedness, ${ }^{(a)}$ the MTF "is intended for use only in circumstances where it is imnediately clear that a proposed action will have no significant environmental impacts." The MTF does not contain an elaborate discussion; rather, it briefly states its basis for concluding that the proposed action will clearly have insignificant environmental effects. If there appears to be a need to support the conclusion with a large amount of material, then an environmental assessment may be necessary to determine whether the action will have significant environmental effects.

DOE Headquarters has delegated authority to its field offices to make some NEPA determinations under some of its programs [Defense Programs (DP), Management and Administration (MA), Fossil Energy (FE), and Energy Research (ER) with the exception of the ER Office of Fusion Energy]. With this delegated authority, field offices such as DOE-RL can make "lower tier" determinations (categorical exclusions, MTFs, action description memoranda [ADM]) for DP, MA, FE and some ER programs. Decisions to prepare an EA or EIS under these programs would remain with $H Q$ program sponsors [in consultation with the Assistant Secretary for Environment, Safety and Health (EH) and the Office of General Counsel (GC)], based on the ADM provided by the field office. At this time, none of the other DOE-HQ program offices [e.g., Nuclear Energy (NE)] have delegated authority to RL to make NEPA determinations. For these programs, the HQ program sponsor (with $\mathrm{EH}$ and $\mathrm{GC}$ ) makes a)1 the NEPA determinations.

(a) U.S. Department of Energy. March 1988. "NEPA Guidance ReTated to Memorandums-to-File and Categorical Exciusions." 
The MTF is prepared by the fieid office, with the EE attached. At RL, a concurrence/approval page is included as part of the MTF (DOE 1987, DOE-RL 1987), with signature blocks for the contractor representative, the DOE Site Management Division, DOE Progran/Project, and DOE Safety and Environment Division (to whom NEPA authority has been redelegated). Once an MTF is prepared, no further HEPA documentation is required and the proposed action may proceed.

When analysis of the EE results indicates that an EIS is required (because of indications that there will be significant environmental effects), or that an EIS may be required (in turn requiring an EA), DOE requires the preparation of an action description memorandum (ADM) as a supporting document.

The action description memorandum (ADM) is not a NEPA document per se and is not discussed in the DOE NEPA guidelines, but is described in the DOE Environmental Compliance Guide (DOE 1981), RL Order 5440.1A, and recent DOE guidance. ${ }^{2}$ An ADM is prepared if a proposed action does not fit clearly into one of the classes of actions 1 isted in Section $D$ of the DOE NEPA guidelines or if it fails the MTF test of "ciearly insignificant" or is not otherwise clearly of insignificant impact.

An ADM contains the following:

- a concise description of the proposed action

- its location

- identification of potential issues.

The description of the action includes the purpose of and need for the proposed action; whether that action is a program, policy, or project; whether the action is legislative or administrative; the type of energy technology involved; and the size of the action. The location of the action is identified by naming the closest city, the county, and the state. Also to be considered for inclusion are characteristics such as rural or urban quality, environmental setting, and economic conditions of the area (DOE 1981). Potential issues include the presence of endangered or threatened species;

(a) U.S. Department of Energy. March 1988. "NEPA Guidance Related to Memorandums-to-file and Categorical Exclusions." 
presence of cultural resources; floodplain or wetlands considerations; and possibility of pollutant emissions to the air, water or soil.

The ADM essentially places the authority for a determination of whether an EA or an EIS is needed in the hands of DOE-EH's Office of NEPA Project Assistance in consultation with GC. For determinations not delegated to the field office, the field office prepares an $A D M$ which is transmitted with the field office's recommendation to the headquarters program office, which passes it on to the Office of NEPA Project Assistance. After consultation with the DOE Office of General Counsel, the Office of NEPA Project Assistance determines whether the action is major with significant environmental effects. If it is not, the Office of NEPA Project Assistance prepares a memorandum from ASEH stating that neither an EA nor an EIS is required and transmits it to the $H Q$ program office, which transmits it to the field office. If it is uncertain whether the action is major with significant environmental effects, $E H$ determines that an $E A$ is required and transmits that information to the program office and field office. If the action is found to be major with significant environmental effects, EH determines that an EIS is required and transmits that information to the program office and field office.

The ADM contains enough information to enable EH to make a determination regarding appropriate documentation, but is not an extensive analytical document.

\subsubsection{Step 3: Prepare the Appropriate NEPA Documentation}

If it has been determined by working through Step 2 that no NEPA documentation (i.e., EA or EIS) is required, the NEPA process ends with either a determination that the action is categorically excluded or is otherwise clearly insignificant (as documented in the MTF). But if it is determined by DDE Headquarters via the ADM or via review of Section $D$ of DOE'S NEPA Guidelines that either an EA or an EIS is required, then that documentation is prepared under this step. 


\section{Timing of Document Preparation}

One of the most important factors in preparing appropriate NEPA documentation is determining when the documentation needs to be prepared. Preparation must be early enough to make the document a useful and integral part of strategic planning and decision making for the implementation of the action, but late enough to ensure that enough environmental and design data exist to provide for a full analysis of environmental impacts and alternatives to the proposed action (Grad 1987). As stated in the CEQ regulations [40 CFR 1502.2(g) and 1502.5 (CEQ 1986b)] and in Jones v. District of Columbia Redevelopment Land Agency (1974), the purpose of the EIS is to assess the future impact of proposed actions, rather than to justify decisions that have already been made. This is why it is so important to integrate the NEPA process into early planning. Also, early integration of future NEPA requirements into the budget cycle will help to ensure that adequate funds are available to prepare HEPA documentation. Thus early consideration saves money, time, and makes subsequent decisions more defensible in terms of NEPA compliance.

The DOE NEPA Guidelines (DOE 1987) instruct DOE to begin preparation of the appropriate environmental document as close as possible to the time that it begins to develop or is presented with a proposal. Further, the document is to be complete before final decision making.

According to the CEQ (1981b), the duration of the EIS process is 1 year, with the possibility that programatic EISs (discussed in Chapter 3) might take longer. CEQ guidance states that the EA process should take about 3 months. However, experience at the Hanford Site and other federal agencies has shown that document preparation and review has taken ionger in some instances. For example, it has been estimated that preparation and review of an EA for Hanford projects can be expected to take from 4 to 9 months, and preparation and review of an EIS from 19 to 36 months (Stalker 1987).

\section{Importance of Concise Documentation}

The CEQ regulations stress the importance of preparing NEPA documentation that focuses on the real environmental issues and that is concise, clear, and to the point [40 CFR 1500.2(b)]. Dinah Bear, General Counse] of 
the CEQ, states that NEPA's usefuiness to decision makers is inhibited by the chronic tendency of agencies to fill NEPA documents with volumes of data and discussions that are often irrelevant and too technical for their intended audiences (Bear 1988). This tendency keeps the NEPA process from fulfilling its aim of being an effective decision-making tool.

Thus, the goal of preparing documentation that efficiently addresses the environmental issues of the proposed action must be kept in mind in preparing the NEPA documents that are discussed below.

\section{Environmental Assessment}

The goal of an environmental assessment is to help determine whether an EIS is required for a proposed action. The EA was created by the CEQ as a mechanism for gathering enough data to determine whether an EIS is required. An EA is not required if an agency has decided to prepare an EIS. The EA briefly provides sufficient evidence and analysis for determining whether to prepare an EIS or a FONS1 and aids an agency's compliance with NEPA when an EIS is necessary by facilitating EIS preparation (40 CFR I508.9).

Once it is decided that an EA is required (either because it states so in Section $D$ of the DOE NEPA Guidelines or because DOE-EH has made that determination, based on the $A D M)$, the DOE field office is responsible for initiating such a document (DOE 1981, 1988c). EH is responsible for approving an EA and subsequently either making a FONSI or a determination that an E1S is required.

According to the EA definition in the CEQ regulations, the EA must include the need for the proposed action, alternatives to the proposed action, the environmental impacts of the action and its alternatives, and a listing of agencies and persons consulted. The format used for Hanford Site EAs is provided in RL 5440.1A and the DOE Environmental Compliance Guide as follows:

1. cover sheet

2. sumary (includes significance of the project and severity of expected impacts) 
3. description of proposed action (drawings, maps and charts, if pertinent)

4. need to undertake the proposed action

5. description of the affected environment

6. alternatives (including "no action")

7. impacts of proposed action and its alternatives (inciuding direct, indirect, beneficial and unavoidable impacts; as well as probable cumulative and long-term impacts)

8. the relationship of the action to applicable federal, state, regional or local land use plans and policies

9. list of agencies and offsite personnel consulted.

There are no page limits for EAs, but the CEQ recommends that EAs be no longer than 10 to 15 pages (CEO 1981b). Background data may be incorporated by reference. The CEO states that lengthy EAs should be avoided where possible, except in cases for which the proposed action is compiex and for which it is very difficult to determine whether the potential effects could be significant.

The outcome of an EA is either a FONSI or a determination that an EIS is required.

\section{Finding of No Significant Impact (FONSI)}

A FONSI is prepared and issued by DOE Headquarters if EH determines, as a result of examining the information provided in an EA, that the proposed action will not significantly impact environmental quality.

DOE makes the FONSI available to the public as part of its efforts to involve the public in preparing and implementing its NEPA procedures (40 CFR 1501.4 and 1506.6). Normaliy the proposed action may be undertaken as soon as a FONSI is issued. The FONSI is to be available for public review (including state- and area-wide clearinghouses) for 30 days before the agency makes its final determination of whether to prepare an EIS and before the action begins (40 CFR 1501.4) in the following circumstances: 
- if the proposed action is, or is very similar to, one that normally requires preparation of an EIS under agency procedures

- if the action is a borderline case (for which it was difficult to discern whether an EIS or a FONSI was appropriate)

- if the action is an unusual case, a new kind of action, or a precedent-setting case such as a first intrusion of even a minor development into a pristine area

- where there is either scientific or public controversy over the proposal (CEQ 1981b).

[In addition, both the Floodplain and Wetlands Executive Orders require that the FONSI be available to the public if the proposed action will be located in floodplains or wetlands (Presidential Executive Orders 11988 and 11990 , respectively, 1985).]

The goal of public notification is to let all interested or affected parties know of the existence of the FONSI. This notification can take place through the Federal Register, notices in national publications and to interested national groups for actions with national significance, and local newspapers for locally or regionally significant actions (DOE 1981).

The FONSI must include the EA or a summary of the EA (40 CFR 1508.13). Its general outline as provided in the DOE Environmental Compliance Guide is

- declaration of finding (including EA surmary or EA as attachment, plus other applicable documents)

- description of proposed action

- alternatives considered

- description of impacts and justification for FONSI

- availability of EA

- contact person.

Most of the court cases that have successfully challenged a FONSI have been on the basis of an agency's having already decided on a FONSI during 
preparation of its EA, (a) making the preparation of an EA a justification of a decision already made.

\section{Environmental Impact Statement}

Most of the guidance on the NEPA process addresses the environmental impact statement. The EIS is the document required by Section $102(2)(C)$ of NEPA. It is a decision-maker's tool; its purposes are to 1) provide agencies with adequate information on which to base their decision whether to proceed with the proposed action and 2) inform the public and give them the chance to participate in information gathering (from Oregon Natural Resources Council v. Marsh 1987; McGarity 1977). Making NEPA documentation publicly available is one means of involving the pubitic.

A section in the CEQ regulations is devoted to discussing ways to reduce paperwork in EIS preparation, and another to instructing agencies on the means by which they can reduce delay (40 CFR 1500.4 and 1500.5 , respectively). It is the goal of the CEQ regulations to encourage concise, clear EISs supported by adequate environmental analysis.

During the EIS process, an agency cannot prejudice the outcome of the proposal by taking any action that would have an adverse environmental impact or limit the choice of reasonable alternatives (40 CFR 1506.1).

Substeps for the EIS process are listed and discussed below:

1. Decide that an EIS is needed.

2. Publish a Notice of Intent.

3. Conduct scoping.

4. Prepare an EIS implementation plan.

5. Prepare a draft EIS.

6. Send out the draft EIS for comments.

7. Prepare and publish the final EIS.

(a) Davis, R. 1987. "Nationai Environmental Policy Act." Presented as part of Government Institutes, Inc. class on Environmental Laws and Regulations, Richland, Washington, September 1987. 
1. Decide that an EIS is needed. The appropriate DOE official decides that a proposed action requires an EIS. The CEQ states that Scoping can be used to help make the decision as to whether to proceed with an EIS, even before a notice of intent (NOI) is published (see below); scoping is not required until after the NOI is published, however (Q. 13, CEQ 1981b).

2. Publish a Notice of Intent. After it is determined that an EIS is necessary, the agency publishes a notice in the Federal Register informing the public, other agencies, etc., that an EIS will be prepared for a proposed action. The NOI serves to alert other agencies and the public that the EIS scoping process is to begin.

According to the DOE NEPA Guidelines and the Environmental Compliance Guide, the NOI must also be disseminated to anyone who has requested it; if the proposed action is of national interest, notices must be mailed to national organizations. For actions of local concern, the NOI is sent to state- and area-wide clearinghouses under OMB Circular A-95, published in local newspapers, sent to potentialiy interested community organizations, distributed through other local media, mailed directly to owners and occupants of nearby or affected property, posted on and offsite in the area of the proposed action, sent to Native American tribes when effects may occur on reservations, and distributed according to the affected state's public notice procedures for comparable actions. The intent of such a wide distribution is to invite conments and suggestions on the proposed scope of the EIS and to encourage public participation in the NEPA process (Section A.4 of DOE NEPA Guidelines).

The comment period for the NOI is at least 20 days.

The DOE Environmental Compliance Guide recomends an outline for the NOI that incorporates the CEQ regulatory requirements ( 40 CFR 1508.22): 
- agency identification

- proposed action and alternatives

- summary of action and purpose of notice

- dates and locations of any hearings

- site description, identification of significant issues, and timing

- invitations for involvement, procedures, availability of related documents

- agency contact point.

3. Conduct scoping. The purpose of EIS scoping is to solicit input from interested persons and agencies on identification of the significant environmental issues that require analysis in an EIS, eliminating those issues that are not important; to ensure that problems are identified and addressed early in the NEPA process; to identify public concerns; and to identify state and local agency requirements that must be addressed (CEQ 1983a).

The NOI invites affected federal, state and local agencies, affected Native American tribes, the proponents of the action, and other interested persons to participate in the scoping process, unless access to the information on the activity must be restricted because of its classified nature. This participation does not necessarily consist of public hearings or meetings, though such a practice is common; the scoping input can be solicited through receipt of scoping compent letters. The choice of participation is left to the discretion of the agency (CEO 1983a).

Case law indicates that such public scoping serves to give interested agencies and persons the opportunity to air their concerns and to participate in the process. The CEQ encourages the agency to notify the public of the results of the scoping process to ensure that all issues have been identified. The results should be documented as well by DOE in its administrative record. 
The DOE NEPA Guidelines [Section A.4(d)] require that if scoping meetings are to held, notice of any scoping meetings is to appear at least 15 days before the meeting.

The CEQ regulations define "scope" as consisting of the range of actions, alternatives, and impacts to be considered in an EIS. The agencies must consider the following (40 CFR 1508.25):

- 3 types of actions

- connected (i.e., they automatically trigger other actions that may require EISs, cannot or will not proceed unless other actions are taken previously or simultaneously, or are interdependent parts of a large action)

- cumulative (which, when viewed with other proposed actions, have cumulatively significant impacts)

- similar (which, when viewed with other reasonably foreseeable or proposed agency actions, have similarities such as common timing or geography that provide a basis for evaluating their environmental consequences together)

- 3 types of alternatives

- no action

- other reasonable courses

- mitigation measures

- 3 types of impacts ("effects" is synonymous with "impacts," according to the regulations)

- direct (caused by the action and occurring at the same time and piace)

- indirect (caused by the action but removed in time and distance; may include growth-inducing effects and other effects relating to changes in land use pattern, population density or growth rate, and related effects on air, water, and other natural systems) 
- cumulative (results from the incremental impact of the action when added to other past, present, and reasonably foreseeable future actions regardless of whether a federal or nonfederal agency or person undertakes such actions).

Other aspects of scoping inciude identifying related environmental review and consultation requirements of other legislation, executive orders, or regulations, so that these can be integrated with the studies required for the EIS (see Chapter 3 ). Examples of such concerns include those pertaining to cultural resources and endangered species.

A memorandum discussing the use of scoping was issued in 1981 by the CEQ and is still available from the General Counsel of the CEQ (Yost 1981). Included in this memorandum are CEQ recommendations on using public scoping effectively in decision making. Also, additional guidance regarding scoping is provided by the CEQ in 48 FR 34263 (CEQ 1983).

4. Prepare an EIS Implementation plan. The EIS implementation plan is a DOE supporting document that records the results of the EIS Scoping process and provides a plan for developing the EIS. The EIS implementation plan is to be completed as soon as practicable after the close of the designated comment period on the NOI, or after any scoping meeting heid, whichever is later (DOE 1987). Section A of the DOE NEPA Guidelines (with 40 CFR 1501.7) states that it must contain 1) the scope and issues to be analyzed in the E1S, 2) an identification and elimination of issues that are not significant or that have previously been covered by environmental review, 3) related environmental assessments or EISs, current or future, for related actions; 4) other environmental review and consultation requirements; 5) the relationship between timing of ElS preparation and the agency's tentative planning and decision-making schedule, 6) a detailed outline of the EIS, and 7) a description of the means 
by which the EIS will be prepared, including any contractor assistance. In addition, the implementation plan may also address target page and time limits, and allocate assignments among DOE and cooperating agencies.

5. Prepare a draft EIS. After the scoping process has ended and the EIS implementation $\mathrm{plan}$ has been completed, the EIS process moves to preparation of the draft EIS. In this document, the environmental impacts of each alternative are considered (including a "no action" alternative, unless Congress has mandated otherwise, as it did in the Nuclear Waste Policy Act of 1982). The document is then circulated for comments from interested federal, state, and local agencies and other affected parties. The draft EIS must fulfill "to the fullest extent possible" the NEPA requirements for a final EIS [40 CFR 1502.9(a)]. Recent work at the Hanford Site provides generic, periodically updated EIS chapters that discuss, for example, the Affected Environment (Cushing 1988). These chapters may be used as a starting point and then tailored to the proposed project.

Content. The format for EISs recommended by the CEQ consists of

- cover sheet

- summary

- table of contents

- purpose of and need for action

- aiternatives, including the proposed action

- affected environment

- environmental consequences

- list of federal permits, licenses, and other entitlements required

- list of preparers 
- distribution list

- index

- appendices, if any.

40 CFR 1502 can be consulted for a detailed description of the content to be addressed in each of these sections. However, a few of the concepts are important enough to be detailed here.

Alternatives. The Alternatives section, which is considered the "heart" of the EIS, presents the environmental impact of the proposed action and all reasonable alternatives (including "no action") in a consistent manner that allows them to be compared to each other. The section must identify the agency's preferred alternative(s) (in the draft EIS, if known) and must consider appropriate mitigation measures. The Alternatives section should describe and compare the alternatives, with a discussion of their environmental impacts that is as concise as possible and is in a form that allows for easy comparison among the alternatives.

The Environmental Consequences section differs from the Alternatives section in that the Environmental Consequences section contains a scientific analysis of the direct and indirect environmental effects of the proposed action and alternatives (Q. 7, CEQ 1981b). This in turn forms the scientific and analytical basis for the comparisons provided in the Alternatives section.

When there seem to be an infinite number of reasonable alternatives, CEQ guidance suggests that the agency address a reasonable number of alternatives which represent the full spectrum. For example, when the U.S. Forest Service is looking into the designation of a wilderness area, it can appropriately consider seven al ternatives that designate $0,10,30,50,70,90$, or 100 percent of the forest (Q. 1, CEQ 1981b).

An agency's preferred alternative is the one that the agency chooses because it would "fulfill its statutory mission and responsibilities, giving consideration to economic, environmental, 
technical and other factors" (Q. 4a, CEQ 1981b). If the agency has identified its preferred alternative during the draft EIS preparation stage, the draft EIS should label this alternative as such. The existence of a preferred aiternative is presumed by the time the final EIS is filed [Q. 4b, CEQ 1981b; 40 CFR 1502.14(e) (CEQ 1986b)].

The environmentally preferable alternative is that which will promote the national environmental policy expressed in NEPA's Section 101. Ordinarily, the environmentally preferable alternative is the one that causes the least damage to the biological and physical environment and is also the one which best protects, preserves, and enhances historic, cultural and natural resources (Q. 6a, CEQ 1981b). The agency must determine which is the environmentally preferable alternative, but it should consider the input of other agencies and the public in making such a decision (Q. 6b, CEQ 1981b).

The "no-action" alternative is easier to define in some situations than in others. The CEQ (Q. 3, 1981b) discusses two types of no-action alternatives. One no-action alternative, the one most commonly thought of, pertains primarily to project proposals, where "no action" means that the proposed activity would not take place. The second type of no-action alternative means "no change" from current management direction or level of intensity.

There are some occasions when alternatives may be outside the scope of the agency to implement, or may be beyond the legal jurisdiction of the agency. If the alternative is outside the agency's scope, it must still be evaluated in the EIS if it is reasonable (Q. 2b, CEQ 1981b). If the alternative is outside the legal jurisdiction of the agency, it must likewise still be analyzed if it is reasonable. However, such conflicts should be discussed in the EIS, as dictated by 40 CFR 1506.2 (Q. 2b, CEQ 1981b). 
Environmental Consequences. The Environmental Consequences section compares the environmental impacts of the alternatives and must include the environmental impact of the proposed action, any adverse environmental effects that cannot be avoided should the action be implemented, the relationship between local short-term uses of man's environment and the maintenance and enhancement of long-term productivity, and any irreversible and irretrievable commitments of resources which would be involved in the proposed action should it be implemented [Section 102(2)(c)(i), (ii), (iv) and ( $v$ ) of NEPA], as well as a discussion of the alternatives to the proposed action (iii), inasmuch as it is necessary to support comparisons within the section. This section should not duplicate the discussions in the Alternatives Section (see below).

The regulations further state that the Environmental Consequences section must discuss these elements:

- direct effects and their significance

- indirect effects and their significance

- possible conflicts between the proposed action and the objectives of federal, regional, state, and local (and with a reservation, Native American tribe) land use pians

- the environmental effects of alternatives, including the proposed action

- energy requirements and conservation potential of various alternatives and mitigation measures

- natural or depletable resource requirements and conservation potential of various alternatives and mitigation measures

- urban quality, historic and cultural resources, and the design of the built environment

- means to mitigate adverse environmental impacts (if not fully covered in the Alternatives section). 
EIS Preparation Responsibility. The draft EIS may be prepared by the lead agency or by a contractor of the lead agency, or portions by a cooperating agency. To avoid a conflict of interest, any contractor preparing an EIS must execute a disclosure statement stating that it has no interest (financial or other) in the outcome of the project.

6. Send out the draft EIS for coments. Public participation in the EIS process, including its comenting role, is one of the major purposes of MEPA. Comments on the draft EIS are to be solicited from appropriate federal, state and local agencies; Native American tribes (when an action may affect a reservation); the applicant (if any); and the public. Some federal agencies are required to comment where they have legal jurisdiction or special expertise with respect to any environmental input involved or where they are authorized to develop and enforce environmental standards [40 CFR 1503.1(a)]. The Office of Management and Budget (OMB) has a system of clearinghouses that can be used to obtain the views of state and local environmental agencies. Hearings may be held to obtain comments but they are not required.

Section 309 of the Clean Air Act Amendments of 1970 authorizes the Administrator of the U.S. Environmental Protection Agency (EPA) to comment in writing on the environmental impact of any matter relating to his or her duties and responsibilities. (EPA also plays a NEPA role by applying the NEPA process to its own review of permit applications.) EPA has in place a rating system that it uses to review draft EISS (EPA 1987, EPA 1984). The ratings for environmental impacts of the action are as follows:

- LO (Lack of Objection)

- EC (Environmental Concerns)

- EO (Environmental objections)

- EU (Environmentaliy Unsatisfactory). 
The EPA ratings for draft EIS adequacy are

- Category 1, Adequate

- Category 2, Insufficient Information

- Category 3, Inadequate.

The EPA provides its rating as a combination of the two ratings;

e.g., EC-2 would indicate the rating "Environmental Concerns-Insufficient Information."

If the EPA Administrator determines that an agency's proposed action will be unsatisfactory from the standpoint of public health or welfare or environmental quality or that a draft EIS is inadequate such that an appropriate determination cannot be made, the Administrator is required to publish this determination and refer the matter to the CEQ (known in the CEQ regulations as "environmental referral").

More information on EPA's role and use of the rating system can be found in EPA Manual 1640 (EPA 1984).

The federal agency must file the draft EIS with EPA; this filing cannot occur until the draft EIS is transmitted to commenting agencies and the public. One copy is sent by EPA to the CEQ. EPA then pubiishes a Federal Register notice of the availability of the draft EIS. Photocopies may be filed with EPA prior to printing only if photocopies are simultaneously made available to other agencies and the public (Q. 28, CEQ 1981b). The time period for commenting on the draft EIS must extend at least 45 days.

7. Prepare and publish the final EIS. The most important aspect of the final EIS is its responses to the comments made on the draft EIS. Comments made on the draft EIS can cause an agency to substantially revisit the information presented and the conclusions drawn in the draft EIS. The following are some ways of responding to comments in the final EIS: 
- modify the alternatives or the proposed action

- deveiop and evaluate heretofore unexamined alternatives

- modify analyses

- correct text

- explain why the comments do not warrant further response on the part of the agency (40 CFR 1503.4).

The final EIS should identify the agency's preferred alternative.

The final EIS, including its conments and responses,

is filed with the EPA, which then transmits a copy to the CEQ

(40 CFR 1506.9).

\subsubsection{Step 4: Make Decisions and Follow Up On Actions}

At this point in the NEPA process, DOE must decide which course of action it will (or will not) take. The CEQ requires that in making its decision, an agency consider all the alternatives considered in the EIS (40 CFR 1505.1).

NEPA does not require that an agency choose the most environmentally protective alternative. Instead, it requires that the effects of agency activities and proposals on environmental quality be considered in the decision-making process (Vanderver and Martin 1987; Vermont Yankee Nuclear Power Corp. v. NRDC 1978).

No decision can be made or recorded on the proposed action until the later of these dates: 1) 90 days following publication in the Federal Register of the EPA notice of filing of a draft EIS, or 2) 30 days following publication in the Federal Register of the EPA notice of filing of a final EIS (40 CFR 1506.10). The CEQ regulations allow the lead agency to extend these periods, and EPA may reduce these time periods, given compelling reasons of national policy. EPA may extend the time period by not more than 30 days, if the lead agency does not concur with a time extension. EPA is required to notify Congress if it revises the time period.

DOE then publishes a "Record of Decision" (ROD) in the Federal Register that shows the alternative chosen and any means employed to mitigate or 
minimize environmental harm (40 CFR 1505.2). The ROD is deemed issued upon the signature of the appropriate DOE official (Section B.2 of the DOE NEPA Guidelines; see Appendix B). The action may proceed no sooner than 90 days after the publishing of the EPA Notice of Filing of the draft EIS or 30 days after the final EIS. DOE recently published the ROD for the Hanford Defense Waste Final EIS (DOE 1988C).

The purpose of the ROD is to relate the EIS process to agency decision making. Doing so ties the ends to the means; it is a way of showing, procedurally, that the agency considered the environmental issues in the EIS in making its decision (CEQ 1978).

The ROD must include a statement of the decision, identify the alternatives considered (including the environmentally preferable alternative), discuss the factors on which preferences among the alternatives were based, and state whether all practicable means to avoid or minimize environmental harm from the selected alternative have been adopted. If such avoidance or mitigation measures were not adopted, the ROD must state the rationale. A monitoring and enforcement program must be adopted and summarized, where applicable, for any mitigation to be conducted.

In implementing the decision of the ROD, the lead agency is to carry out any mitigation and other conditions specified in the EIS and committed to in the ROD. Agencies may provide for monitoring of the action, and the CEQ advises that they do "in important cases" (40 CFR 1505.3). 


\subsection{NEPA IMPLEMENTATION ISSUES IMPORTANT TO THE HANFORD SITE}

Although NEPA has been in existence for almost two decades, a number of NEPA concepts remain unclear and implementation issues still exist, because of the subjective nature of the process and the lack of definitive, detailed guidance in some areas. Also, NEPA rulings by the courts can sometimes lead to new interpretations of the issues. This chapter discusses some of these major NEPA concepts and issues currently important to NEPA implementation on the Hanford Site:

- threshold question

- programatic and supplemental EISs

- other environmental requirements

- worst-case analysis

- mitigation.

The discussion of each of these items is intended to be an explanation and an introduction of an issue, rather than a definitive analysis of the concept/issue and its potential repercussions.

\subsection{THRESHOLD QUESTION}

As mentioned in Chapter 2, the primary concern of the NEPA regulations and guidance is with the "action-forcing" provisions of NEPA's Section 102(2), which, among other things, require "a detailed statement. . . for those major federal actions significantly affecting the quality of the human environment" (see Figure 1.1). Answering this threshold question is the crux of NEPA and deserves some discussion here. The threshold determination can be one of the more difficult to make, for the statute, regulations and guidance do not contain stringent or detailed threshold criteria for agency use in making these determinations. Thus the basis for making decisions on the appropriate level of NEPA documentation is not easy and relies heavily on subjective reasoning. Even a look at how the courts have ruled in similar instances does not provide a definitive answer as to whether an EIS is required before undertaking a planned action. For example, 
"'significance' has been defined in court cases to range from 'not trivial" through 'appreciable' to 'important' and even 'momentous'" (cases cited in GIitzenstein 1982).

We do, however, have some limited guidance from the CEQ in their definitions of "major federal action," "significantly," and "human environment."

The first important point in answering the threshold question is to realize that the CEQ regulations define "major" only in the context of its effects; that is, it can be read that for a federal action with significant environmental effects, whether the action is major or minor is of little consequence to the threshold question. The definition of "major federal action" "includes those actions with effects that may be major. . . Major reinforces but does not have a meaning independent of significantly" [CEO 1986b; Colorado River Indian Tribes v. Marsh 1985 in Bell 1985].

The term "significantly," the most important element of the threshold question, is defined in the CEQ regulations (see figure 3.1). This definition is probably the most useful one available for addressing the threshold issue for a given project.

The CEQ regulations define "human environment" to include the natural and physical environment and the relationship of people to the environment. Further, federal case law indicates that "human environment" includes its social, aesthetic and cuitural aspects (Rogers 1977). However, social or economic effects in and of themselves cannot trigger the requirement for an EIS.

\subsection{PROGRAMMATIC AND SUPPLEMENTAL EISS}

An understanding of the nature of the specialized types of EISs known as programatic and supplemental EISs is important to Hanford Site work. Currently there are several major programs/projects that may require either of these types of NEPA documentation. The concept of programatic and supplemental EISs and how they relate in turn to "tiering" of NEPA documentation are explained below. 
- 1508.27 Significantly.

"Significantly" as used in MEPA

requires considerations of both con-

text and intensity:

(a) Context. This means that the significance of an action must be analyzed in several contexts such as society as a thole (husan, national), the affected region, the affected interests, and the locality. Significance varies with the setting of the proposed action. For instance, in the case of a site-specific action, significance would usually depend upon the effects in the locale rather than in the world as a wole. Both shortand long-tere effects are relevant.

(b) Intensity. This refers to the severity of impact. Responsible officials must bear in aind that wore than one agency may make decisions about partial aspects of a major action. The following should be considered in evaluating intensity:

(1) Impacts that way be both beneficial and adverse. A significant effect way exist even if the Federal agency believes that on bal ance the effect will be beneficial.

(2) The degree to wich the proposed action affects public health or safety.

(3) Unique characteristics of the geographic area such as proxieity to historic or cultural resources, park lands, prime farmlands, metl ands, vild and scenic rivers, or ecologically critical areas.

(4) The degree to wich the effects on the quality of the huran environent are likely to be highly controversial.

(5) The degree to wich the possible effects on the huan enviroment are highly uncertain or involve unique or unknom risks.

(6) The degree to which the action ay establish a precedent for future actions with significant effects or represents a decision in principle about a future consideration.

(7) Whether the action is related to other actions with individually insignificant but cunulatively significant impacts. Significance exists if it is reasonable to anticipate a cumblatively significant impact on the environeent. Significance cannot be avoided by terming an action teiporary or by breaking it down into saall comonent parts.

(8) The degree to wich the action may adversely affect districts, sites, highways, structures, or objects listed in or eligible for listing in the Mational Register of Historic Places or way cause loss or destruction of significant scientific, cultural, or historical resources.

(9) The degree to wich the action way adversely affect an endangered or threatened species or its habitat that has been determined to be critical under the Endangered Species Act of 1973.

(10) Whether the action threatens a violation of Federal, State, or local law or requirements icposed for the protection of the enviromient.

[43 FR 56003, Nov. 29, 1978; 44 FR 874, Jan. 3, 1979.]

FIGURE 3.1. CEQ's Regulatory Definition of "Significantly" as Used in Section $102(2)(C)$ of NEPA 
There are times when an EIS or an EA covers an aspect of a program, proposal or project that is narrower in scope or is at a later stage than an EIS prepared previously. Through the use of a CEQ NEPA concept called tiering, these subsequent EISs or EAs may incorporate by reference or may summarize the material presented in the earlier, broader EISs. The intent of tiering is to eliminate duplicative documentation and discussions and allow federal agencies to focus on the issues "ripe for discussion" [40 CFR 1500.4(i)]. Tiering can take place 1) from a program, plan or policy EIS [i.e., a programbatic EIS] to a statement or analysis of lesser scope or of a more sitespecific nature; or 2) from a project-specific EIS prepared at an early stage in the project, to a supplement (preferred) or to a subsequent statement or analysis at a later stage in the project (such as environmental mitigation) (40 CFR 1508.28).

A discussion of tiering logically leads to a discussion of programatic and supplemental EISs, two types of E1Ss potentially relevant to Hanford Site activities.

A programatic EIS is generally prepared to cover the projected effects of the implementation of broad, general federal programs or policies. It is defined by Rogers (1977) as "comprehensive analyses of agency programs involving numerous actions with environmental effects." Programmatic EISs would also be appropriate for a group of related actions, a specific statutory program [such as CERCLA cleanup], or an executive directive (Q. 24a, CEQ 1981b). A programmatic EIS may also be appropriate for actions related to one another on the basis of timing or geography (for example, a number of agency projects in a single watershed) (Q. 24b, CEQ 1981b). Programmatic EISs cover such programs as commercial radioactive waste management (DOE 1980), river basin studies by the Army Corps of Engineers, dam projects by the Bureau of Reclamation, and federal coal leasing by the Bureau of Land Management (Rogers 1977).

A programmatic E1S allows the agency and the EIS reviewers to more clearly see 1) the alternatives to the proposed action (segmentation of programs into individual projects can easily obscure alternatives); 
2) cumulative impacts which, because of synergistic effects, can be greater than the sum of separate effects; and 3) the full range of environmental impacts (McGarity 1977).

Subsequent site-specific actions under the umbrella of a programmatic EIS may or may not require additiona1 NEPA documentation (CEQ 1983a). Subsequent EISs are necessary when such actions have significant environmental impacts that were not adequately evaluated in the programmatic EIS (Rogers 1977). Also to be considered is whether a commitment to prepare a supplement has been made in earlier related documentation. A progranmatic EIS may be the easiest way to address the cumulative impacts of a series of related projects to be covered by site-specific documentation.

Supplements to EISS are required for draft or final EISs on either of two occasions:

1. if substantial changes have been made in the proposed action that are relevant to environmental concerns

2. if significant new circumstances have arisen or information has been found that is relevant to environmental concerns and bears on the proposed action or its impacts (40 CFR 1502.9).

According to the CEQ (1983a), the use of tiering should reduce the number of occasions on which a supplemental EIS is needed.

Where it is unclear whether a supplemental EIS is required, the DOE NEPA Guidelines (Section C.2) state that DOE will prepare an analysis that provides sufficient information to support a DDE determination under the requirements of 40 CFR 1502.9(c)(i) and (ii). Based on this analysis, DOE will determine whether to prepare an EIS supplement. If it determines that a supplemental EIS is not required, DOE will prepare a brief memorandum that explains the basis for that determination. Further, either this memorandum and analys is or the supplement is to be incorporated into any related formal administrative record prior to making a final decision on the action in question. 


\subsection{OTHER ENVIRONMENTAL REQUIREMENTS}

A question that often arises during the NEPA process is what other statutory and regulatory requirements are appiicable to the action at hand, and how the NEPA process can be integrated with the compliance process of these other statutes and their implementing regulations.

As stated in Section C.4 of the DOE NEPA Guide] ines, 40 CFR 1502.25 provides for integration of the NEPA process with other environmental requirements. The Guidelines specifically direct DOE to

- coordinate NEPA compliance with other environmental review requirements

- determine the applicability of other environmental requirements early in the planning process to ensure compliance and avoid delays

- include in draft and final EISs plans and estimated schedules for compliance with other applicable environmental review requirements

- use the relevant NEPA document to support the fulfillment of the review and documentation requirements of other statutes and regulations and to report the status of compliance with these other environmental authorities.

For example, some of the current issues regarding other environmental requirements relate to how NEPA environmental review can be conducted in a coordinated manner with the requirements of RCRA and CERCLA for Hanford and other DOE site cleanup actions. DOE Notice 5400.4, "Integration of Environmental Compliance Processes," has recently been released by DOE Headquarters (DOE 1988b). This notice establishes a policy "to integrate the requirements of NEPA with the planning and environmental review procedures of the CERCLA RI/FS [Remedia] Investigation/Feasibi]ity Study] process so that such procedures run concurrently rather than separately."

CEQ regulation 40 CFR 1502.25 requires agencies, "to the fullest extent possible," to prepare draft EISs concurrently with and integrated with environmental impact analyses and related surveys and studies required by the Fish and Wildlife Coordination Act, the National Historic Preservation Act, the Endangered Species Act, and other environmental review 1 aws and executive 
orders. A list of other federal environmental statutes and Executive Orders potentially applicable to Hanford Site activities is provided in Table 3.1.

Obtaining the necessary permits to conduct activities is an important part of compliance with these other environmental statutes and regulations.

TABLE 3.1. Other Federal Environmental Statutes and Executive Orders Applicable or Potentially Applicable to DOE Activities at Hanford

General

EO 12088, Federal Compliance with Pollution Control Standards, as anended by EO 12580, Superfund Implenentation Pollution Control

Comprehenaive Environment Resporse, Componsation and Liability Act, 42 USC $901-9657$

Taxic substances control Act, is usc $2601-2629$

Federal Inecticide, Fungicide and Rodenticide Act, 7 usc 136-136y

Cleen Air Aet, 22 usc 7401 et seq.

Hoise Control Act, 42 USC $4901-4918$

Cleen Hater Act, 33 USC 181 et seq.

Safe Drinking Water Act, 33 USC $400 f$ et seq.

Reacurce Conservation and Recovery Act, 42 usc $6901-6897$

Culturel Reacurcers

Nationsl Historic Preservation Act, 16 USC 470 et seq.

EO 11593, Protection ard Enhancenent of the Culturat Envirorment

Historic sites, Buildings and Antiquities Act, is USC 461-467

Archaeological and Historic Preservation Act, 16 USC 469-469

Anerican Indian Religious freedon Act, 42 USC 1996

Archaeological Resources Protection Act, 16 USC 470a-4701

Antiquities Act, 16 usc $431-433$

Naturgi Resources

Endengered Species ACt, 16 USC 1531-1543

Bald and Golden Eagle Protection ACt, 16 USC $\$ 68-6680$

Higratory aird Treaty Act, 16 USC 703-712

Fish and Wildlife coordination Act, 16 USC 669.666

Rivers and Harbors Appropriation Act, 33 USC 401-403

Uild and Scenic Rivers Act, 16 USC 1271-1287

Land Use

Floctplain/wetlands Execut ive Orders 11988 and 11990 
NEPA documentation is a necessary part of the permitting process. Permitting agencies follow the NEPA process for their review of permit applications; i.e., they will determine whether the granting of a permit to another agency constitutes a major federal action significantly affecting environmental quality. Examples of environmental permits for Hanford, and the permitting agencies, are

- NPDES (National Pollutant Discharge El imination System) permits, required for discharging effluents to surface waters such as the Columbia River (U.S. Environmenta] Protection Agency)

- PSD (prevention of significant deterioration) permits, for air emissions of constituents above certain concentrations (U.S. Environmental Protection Agency and Washington Department of Ecology)

- TSD (treatment, storage or disposal) permits, required for the operation of TSD facilities for management of hazardous waste (Washington Department of Ecology).

In addition, there are important agency consultation and environmental review requirements under such statutes as the National Historic Preservation Act, for cultural resources, and the Endangered Species Act, for threatened and endangered plant and animal species. Table 3.2 provides a list of selected federal environmental statutes and executive orders and the agencies responsible for implementation.

Under a Hanford program to develop a consistent, easily updated frame of reference for EIS chapters, a reference EIS chapter on Statutory and Regulatory Requirements has been developed (Cushing 1988). The purpose of this chapter is to present information that can be adapted, with modifications appropriate to the specific action, to future Hanford Site EISs. The chapter identifies federal laws, regulations, DOE orders, and permits generally applicable to the Hanford Site.

Another environmental review requirement springs from the Washington State Environmental Policy Act (SEPA) (Revised Code of Washington 43.21C), which is similar in form and intent to NEPA. SEPA's enforcement is delegated 
SEPA applies to actions of all branches of state government, including state agencies, municipal and public corporations, and counties [RCW 43.21C.030(2)] including the granting of permits by state agencies. Thus the applicability of SEPA to the Hanford Site rests on whether state or local permits are required for Hanford activities. If so, the state agency may apply SEPA to its activities in relation to a permit application by a federal agency such as DOE. The Washington Department of Ecology (which enforces the state RCRA program) has, in fact, asked DOE-RL to complete SEPA checklists (see Appendix $D$ ) as part of its Treatment Storage or Disposal (TSD) facility Part B permit applications and closure/postclosure plan submittals.

RCW 43.21C.150 states that SEPA's requirement for a detailed statement is not applicable when an adequate detailed statement has been prepared pursuant to NEPA, and that NEPA documentation can be used in lieu of SEPA documentation. According to WAC 197-11-610, a state or local agency may adopt any environmental analysis prepared under NEPA by following specific regulatory requirements at WAC 197-11-600 and -630 , which require the adopting agency to independently review the document and determine that it meets that agency's environmental review standards and needs for the proposal. A NEPA EA can be adopted to satisfy the requirements for a Determination of Nonsignificance (ONS) or an EIS. A NEPA EIS may substitute as a SEPA EIS if WAC 197-11-600 and -630 are followed and if the federal EIS is not found inadequate by a court, by the CEQ, or by the EPA.

On the NEPA side, the CEQ regulations (40 CFR 1506.2) discuss cooperation between federal and state/local agencies. They specifically state that where state laws or local ordinances have EIS requirements in addition to but not in conflict with NEPA's, the federal agency must cooperate in fulfilling these requirements as well as those of federal laws so that one document will comply with all applicable laws.

\subsection{WORST-CASE ANALYSIS}

The question of whether a worst-case analysis is required as part of EIS preparation and documentation was thought to have been laid to rest with 
CEQ's amendment of 40 CFR 1502.22 in 1986 (CEQ 1986a), which rescinded the worst case-analysis requirement. However, two recent Ninth Circuit Federal Court of Appeals decisions appear to still require a worst-case analysis, as discussed below.

Section 1502.22 of the CEQ regulations states that if the information relevant to reasonabiy foreseeable significant adverse impacts cannot be obtained because the overall costs of obtaining it are exorbitant or the means to obtain it are not known, the agency must in its EIS disclose the fact that the information is incomplete or unavailable; then it must discuss why this incomplete or unavailable information is relevant to the evaluation; then it must present a summary of existing credible scientific evidence relevant to evaluating the reasonably foreseeable significant adverse impacts on the human environment; and finally, it must include the agency's evaluation of such impacts based on theoretical approaches or research methods general1y accepted in the scientific community. While the agency must include in its evaluation those reasonably foreseeable potential impacts that have a low probability of occurrence but which would result in catastrophe if they occurred, the analysis cannot be based on pure conjecture or remote and highly speculative consequences (CEQ 1986a).

In recent court actions (Oreqon Natural Resources Council v. Marsh [1987] and Methow Valley Citizens Council v. Regional Forester [1987]), the Ninth Circuit Federa] Court of Appeals held that the rescission "does not nullify the requirement (for a worst-case analysis), since the regulation was merely a codification of prior NEPA caselaw" (cited in Environmental Law Reporter, 18 ELR 20163-20167). That is, although the CEQ has removed the requirement for a worst-case analysis from its regulations, some court decisions have still upheid the requirement. On the other hand, a more recent ruTing (No Gmen Alliance of Lane County v. Aldridge, 9th Cir. 86-4082, March 9,1988 ) by the same Ninth Circuit quotes with approval Section 1502.22. In any event, the U.S. Supreme Court agreed on June 27, 1988, to review the Ninth Circuit decisions in Oregon Natural Resources Councilv. 
Marsh and Methow Valley Citizens Council v. Regional Forester. (a) These will be the first NEPA cases the Supreme Court has reviewed since 1983.

\subsection{MITIGATION}

If mitigation is appropriate for lessening the effects of an activity, even though the activity's effects may not be "significant," then an EA should discuss these mitigation measures or alternatives to "assist in agency planning and decision making" and to "aid an agency's compliance with [NEPA] when no environmental impact statement is necessary" [40 CFR 1501.3(b) and 1508.9(a) (2), as cited in CEQ 1981b]. These mitigation measures can be written into a permit or can be adopted as agency policy in carrying out the proposed activity.

Along these lines, a much-debated and complex legal question regarding mitigation has been whether implementation of mitigation measures can be used to circumvent the need for preparing an EIS, i.e., whether the environmental effects of the proposed action can be reduced from significant to insignificant through the use of mitigation, and a FONSI prepared. Case law and guidance are not entirely clear as to whether mitigation can absolve agencies of the need to prepare an EIS for previously significant impacts that have been reduced by mitigation to a level of insignificance. However, CEQ's Deputy General Counsel, Lucinda Swartz, has stated that a FONSI can be based on mitigation plans only if they are required in a permit. A FONSI cannot be based on mitigation if mitigation measures are only discussed in the EA and there is no way to ensure enforcement. Additionally, she noted that a bill is likely to be introduced in Congress (expected to pass in 1989) that would require review of a statistically significant number of NEPA documents to determine if mitigation comitments have been fulfilled.

(a) R. L. Hames, private communication, March 1989.

(b) DOE memo and attachments from C. M. Borgstrom, Director, Office of NEPA Project Assistance; December 1, 1988. 


\subsection{REFERENCES}

Bear, D. Jan.-Feb. 1988. "Does NEPA Make a Difference?" EPA Journal.

Bell, C. R. 1985. Federal Historic Preservation Case Law. Advisory Council on Historic Preservation, Washington, D.C.

Black, H. C. 1983. Black's Law Dictionary, 5th ed. West Publishing Co., St. Paul, Minnesota.

Calvert Cliffs' Coord. Committee v. Atomic Energy Commission. 1971. 449 F.2d 1109 (D.C. Cir. 1971).

Council on Environmental Quality (CEQ). 1978. "NEPA Regulations." 43 Federal Register 55990, November 28, 1978.

Council on Environmental Quality (CEQ). 1980. Environmental Quality, 11th Annual Report. U.S. Government Printing Office, Washington, D.C.

Council on Environmental Quality (CEQ). 1981a. Environmental Quality, 12th Annual Report. U.S. Government Printing Office, Washington, D.C.

Council on Environmental Quality (CEQ). 1981b. "Forty Most-Asked Questions Concerning CEQ's National Environmental Policy Act Regulations." 46 Federal Register 18026, March 23, 1981.

Council on Environmental Quality (CEQ). 1982. Environmental Quality, 13th Annual Report. U.S. Government Printing Office, Washington, D.C.

Council on Environmental Quality (CEQ). 1983a. Guidance Regarding NEPA Regulations. 48 Federal Register 34263, July 28, 1983.

Council on Environmental Quality (CEQ). 1983b. Environmental Quality, 14th Annual Report. U.S. Government Printing Office, Washington, D.C.

Council on Environmental Quality (CEQ). 1985. Environmental Quality, 16th Annual Report. U.S. Government Printing Office, Washington, D.C.

Council on Environmental Quality (CEQ). 1986a. "National Environmental Policy Act Regulations; Incomplete or Unavailable Information." 51 Federal Register 15618-15621, April 25, 1986.

Council on Environmental Quality (CEQ). 1986b. Regulations for Implementing the Procedural Provisions of the National Environmental Policy Act. Reprint of 40 CFR 1500-1508 as of July 1, 1986, U.S. Government Printing 0 ffice, Washington, D.C. 
Cushing, C. E., ed. 1988. Hanford Site National Environmental Policy Act (NEPA) Characterization. PNL-6415 Rev. 1, Pacific Northwest Laboratory, Richland, Washington.

Garver, G. 1986. "A New Approach to Review of NEPA Findings of No Significant Impact." Michigan Law Review 85:191-216.

Glitzenstein, E. 1982. "Project Modification: Illegitimate Circumvention of the EIS Requirement or Desirable Means to Reduce Adverse Environmental Impacts?" Ecology Law Quarterly 10:253-280.

Grad, F. P. 1987. Treatise on Environmental Law. Volume 2, Cumulative Supplement. Bender \& Co., Albany, New York.

Jones v. District of Columbia Redevelopment Land Agency. 1974. 499 F.2d 502 .

MacDonne11, L. J. 1988. "Natural Resources Dispute Resolution: An Overview." In Environmental Dispute Resolution, University of New Mexico Law Journal, vol. 28, Winter 1988. Albuquerque, New Mexico.

McGarity, T. 0. 1977. "The Courts, the Agencies, and NEPA Threshold Issues." Texas Law Review 55:801-887.

Methow Valley Citizens Council v. Regional Forester. 1987. In 18 Environmental Law Reporter 20163-20167.

No Gwen Alliance of Lane County v. Peterson. 1988. 510 F.Supp. 1186, 11904 (D.D.C).

Oregon National Resources Council v. Marsh. 1987. In 17 Environmental Law Reporter 21025.

Presidential Executive Order 11988, "Floodplain Management," 42 Federal Register 26951 (May 24, 1977).

Presidential Executive Order 11990, "Protection of Wetlands," 42 Federal Register 26961 (May 24, 1977).

Revised Code of Washington (RCW). 1987. "State Environmental Policy." RCW 43.21C, 0lympia, Washington.

Rogers, W. H., Jr. 1977. Environmental Law. West Publishing Company, St. Paul, Minnesota.

Stalker, A. K. 1987. Pacific Northwest Laboratory National Environmental Policy Act Project Compliance Plan. Pacific Northwest Laboratory, Richland, Washington. 
U.S. Department of Energy (DOE). 1980. Final Impact Statement: Management of Commercially Generated Radioactive Waste. DOE/EIS-0046F, U.S. Department of Energy, Washington, D.C

U.S. Department of Energy (DOE). 1981. Environmental Compliance Guide. DOE/EV-0132, U.S. Department of Energy, washington, D.C.

U.S. Department of Energy (DOE). 1985. "Implementation of the National Environmental Policy Act." DOE Order 5440.1C.

U.S. Department of Energy (DOE). 1987. "DOE NEPA Guidelines." 52 Federal Register 47663, December 15, 1987.

U.S. Department of Energy (DOE). 1988a. "Compliance with the National Environmental Policy Act." 10 Code of Federal Regulations 1021. (Originally published at 44 Federal Register 45918, August 6, 1979).

U.S. Department of Energy (DOE). 1988b. "Integration of Environmental Compliance Process." DOE N5400.4, Washington, D.C.

U.S. Department of Energy (DOE). 1988c. "Record of Decision on High-Level Defense Waste EIS." 53 Federal Register 12449, April 14, 1988.

U.S. Department of Energy, Richland Operations Office (DOE-RL). 1987. "Implementation of the National Environmental Policy Act at the Richland Operations Office." DOE-RL Order 5440.1A.

U.S. Environmental Protection Agency (EPA). 1984. Policy and Procedures for the Review of Federal Actions Impacting the Environment. EPA Manual 1640, U.S. Envíronmental Protection Agency, Washington, D.C.

U.S. Environmental Protection Agency (EPA). 1987. "Environmental Impact Statements and Regulations; Availability of EPA Conments." 52 Federal Register 13749, April 24, 1987.

Vanderver, T. A., Jr., and J. C. Martin. 1987. "National Environmental Policy Act." In Environmental Law Handbook, 9th ed. Government Institutes, Inc., Rockville, Maryland.

Vermont Yankee Nuclear Power Corp. v. NRDC. 1978. 435 U.S. 519, 558. Washington Administrative Code (WAC). 1986. "SEPA Rules." WAC-197-11, Olympia, Washington.

Yost, N. C. 1981. "Memorandum for General Counsels, NEPA Liaisons and Participants in Scoping: Scoping Guidance." Council on Environmental Quality, Washington, D.C. 
APPENDIX A

THE LOCATIONS OF MAJOR NEPA CONCEPTS IN REQUIREMENTS ANO GUIDANCE DOCUMENTS 
TABLE A.1. The Locations of Major NEPA Concepts in Requirements and Guidance Documents

\begin{tabular}{|c|c|c|c|c|c|c|c|c|c|}
\hline CONCEPT & MEPA SIATUTE & CEO REGS & DOE CUIDELLINES. & $\begin{array}{l}\text { DOE ORDER } \\
5440,1 C \\
\end{array}$ & $\begin{array}{l}\text { RL OPDER } \\
5440.11 \\
\end{array}$ & $\begin{array}{c}\text { ENVIRONAENTAL } \\
\text { CONPLINANCE } \\
\text { GUIDE. } \\
\end{array}$ & $\begin{array}{c}\text { CEQ': } 40 \\
\text { MOST ASKED } \\
\text { QUESTIOHS } \\
\end{array}$ & $\begin{array}{l}48 \mathrm{FR} \\
34263\end{array}$ & $\begin{array}{c}3 / 25 / 88 \\
\text { DOE } \\
\text { MEMO } \\
\end{array}$ \\
\hline \multicolumn{10}{|l|}{ NEPA DOCLMENTATIO } \\
\hline $\begin{array}{l}\text { Envirormentel } \\
\text { Assessment (EA) }\end{array}$ & $\cdots$ & $\begin{array}{l}1501.3 \\
1501.4(b),(c) \\
1506.5(b) \\
1508.9\end{array}$ & $A .3(c)$ & $\begin{array}{l}\sec .4(b) \\
\sec .6(a) \\
\text { sec.6(b) } \\
\text { Sec.6(e) }\end{array}$ & $\begin{array}{l}\text { Att.3 } \\
\text { sec. } 6(c) \\
\text { Sec. } 9(b)(2) \\
9(d)(3) \\
10(b)\end{array}$ & $\begin{array}{l}11-2 \\
11-4 \\
11-5 k \\
1.2\end{array}$ & $\begin{array}{l}0.36,38,39 \\
40\end{array}$ & $x$ & $\cdots$ \\
\hline $\begin{array}{l}\text { Finding of Wo sig- } \\
\text { nificant I apect } \\
\text { (fousI) }\end{array}$ & - & $\begin{array}{l}1500.3 \\
1500.4(q) \\
1500.5(1) \\
1501.4(e) \\
1508.13\end{array}$ & -- & $4(c)$ & $\begin{array}{l}6(c) \\
\text { Att.3 }\end{array}$ & $\begin{array}{l}11-2 \\
11-5(b) \\
4.3\end{array}$ & $\begin{array}{l}0.37,38 \\
39,40\end{array}$ & $x$ & $-\cdot$ \\
\hline $\begin{array}{l}\text { Notice of Intent } \\
\text { (NOI) }\end{array}$ & $\because$ & $\begin{array}{l}1501.7 \\
1507.3(\mathrm{e}) \\
1508.22\end{array}$ & A.4(B) & -- & -- & $\begin{array}{l}11-2 \\
\text { A.5 }\end{array}$ & - & -- & $\because$ \\
\hline $\begin{array}{l}\text { Record of Decision } \\
\text { (RD) }\end{array}$ & $\cdot-$ & $\begin{array}{l}1505.2 \\
1506.1\end{array}$ & $8.2(6)(5)$ & $4(f)$ & $\begin{array}{l}\text { Att.3 } \\
\text { 6(e) }\end{array}$ & $\begin{array}{l}11-2 \\
11-7 \\
1.11\end{array}$ & 0.34 & -- & -- \\
\hline \multicolumn{10}{|c|}{ Enviromental lmpact statement (EIS) } \\
\hline format for Eis & $-\cdot$ & 1502.10 & $A .4(e)(2)(1,1 i)$ & -- & $9(b)(4)$ & A.7 & $\begin{array}{l}0.25,26 \\
27,28\end{array}$ & $\cdot-$ & $\because$ \\
\hline Comments/Responses & $\cdots$ & $\begin{array}{l}1502.19 \\
1503.1-.4 \\
1506.6(f)\end{array}$ & $A .4(c)$ &.- & -- & $\begin{array}{l}\text { A.8 } \\
\text { A.9 }\end{array}$ & 0.29 & -- & $\cdots$ \\
\hline $\begin{array}{l}\text { When to Prepare } \\
\text { EIS }\end{array}$ & $\cdots$ & 1501.3 & $\cdots$ & -. & - & - & $\cdots$ & $\cdots$ & $\cdots$ \\
\hline $\begin{array}{l}\text { Whether to } \\
\text { Prepare EIS }\end{array}$ & $\cdots$ & 1501.4 & $\begin{array}{l}\text { A.3 } \\
\text { Section } 0\end{array}$ & -- & $\cdots$ & -- & -- & $\cdots$ & $\cdots$ \\
\hline $\begin{array}{l}\text { Contractor Prepa- } \\
\text { ration of EIS }\end{array}$ & $\because$ & $1506.5(c)$ & $\begin{array}{l}\text { A. } 4(e)(1) \\
\text { (iii) }\end{array}$ & $\cdots$ & $\cdots$ & $-\theta$ & $0.16,17$ & $x$ & $\cdots$ \\
\hline
\end{tabular}


TABLE A.1. (contd)

\begin{tabular}{|c|c|c|c|c|c|c|c|c|c|}
\hline CONCEPT & NEPA STATUTE & CEQ REGS & DOE QUIOELINES & $\begin{array}{c}\text { DOE ORDER } \\
5440.1 \mathrm{C}\end{array}$ & $\begin{array}{l}\text { RL ORDER } \\
5440,14 \\
\end{array}$ & $\begin{array}{c}\text { EWVIRONHENTAL } \\
\text { COMPL IANCE } \\
\text { OIDEE } \\
\end{array}$ & $\begin{array}{l}\text { CEO's } 40 \\
\text { WST ASKED } \\
\text { QUESTIOWS } \\
\end{array}$ & $\begin{array}{l}48 \mathrm{FR} \\
34203\end{array}$ & $\begin{array}{c}3 / 25 / 88 \\
\text { DOE } \\
\text { MENO } \\
\end{array}$ \\
\hline \multicolumn{10}{|l|}{ EIS (contd) } \\
\hline EPA's Role & $\cdot \cdot$ & $\begin{array}{l}1502.11(f) \\
1504.1 \\
1504.3 \\
1506.7(\mathrm{c}) \\
1506.9 \\
1506.10 \\
1508.19(\mathrm{~d})\end{array}$ & $\cdots$ & $\cdots$ & $\cdots$ & A.9. & 0.15 & -- & $\because$ \\
\hline Draft EIS & $\cdots$ & $1502.9(a)$ & $\cdots$ & -- & -- & $\begin{array}{l}11-2 \\
11-\delta(b)\end{array}$ & $\cdots$ & -. & \\
\hline Final Ess & -- & $\begin{array}{l}1502.9(b) \\
1503.1 \\
1503.4(b)\end{array}$ & $\cdots$ & -- & -. & $\begin{array}{l}I J-2 \\
11-6(b)\end{array}$ & $\cdots$ & . & \\
\hline supplemental EIs & $\because$ & $1502.0(c)$ & c.2 & $\therefore$ & $\cdots$ &.- & 0.32 & $x$ & \\
\hline Progranmat ic EIS & $\ldots$ & $\begin{array}{l}1500.4(3) \\
1502.4 \\
1502.20 \\
1508.18\end{array}$ & $\because$ &.- & $\cdots$ & $\cdots$ & $0.24,35$ & $x$ & \\
\hline Effects & $102(2)(c)$ & $\begin{array}{l}1502.16 \\
1508.8\end{array}$ & $0.3(c)(2)(1 i i)(c)$ & -- & - & $\begin{array}{l}11-4 \\
11-2\end{array}$ & 0.18 & -. & -. \\
\hline Impects & $102(2)(c)$ & $\begin{array}{l}1508.8 \\
1508.25(\mathrm{c})\end{array}$ & $0.3(c)(2)(111)(c)$ & -. & - & A. 7 & $\cdots$ & .. & - \\
\hline $\begin{array}{l}\text { Incomplete or } \\
\text { Unavailable } \\
\text { information }\end{array}$ & $\cdots$ & 1502.22 & $-\cdot$ & $-\cdot$ & - & -- & -+ & .. & $\cdots$ \\
\hline $\begin{array}{l}\text { Lead/Cooperating } \\
\text { Agency }\end{array}$ & $102(2)(c)$ & $\begin{array}{l}1501.1(b),(c) \\
1501.5 \\
15001.6 \\
1503.1(a)(1) \\
1503.2 \\
1503.3 \\
1504.3 \\
1506.3(c) \\
1508.5 \\
1508.16\end{array}$ & $\cdots$ & $\cdots$ & $\cdots$ & $11-6(a) 30,31$ & $0.14,23$ & $x$ & $\therefore$. \\
\hline
\end{tabular}


IABLE A.1. (contd)

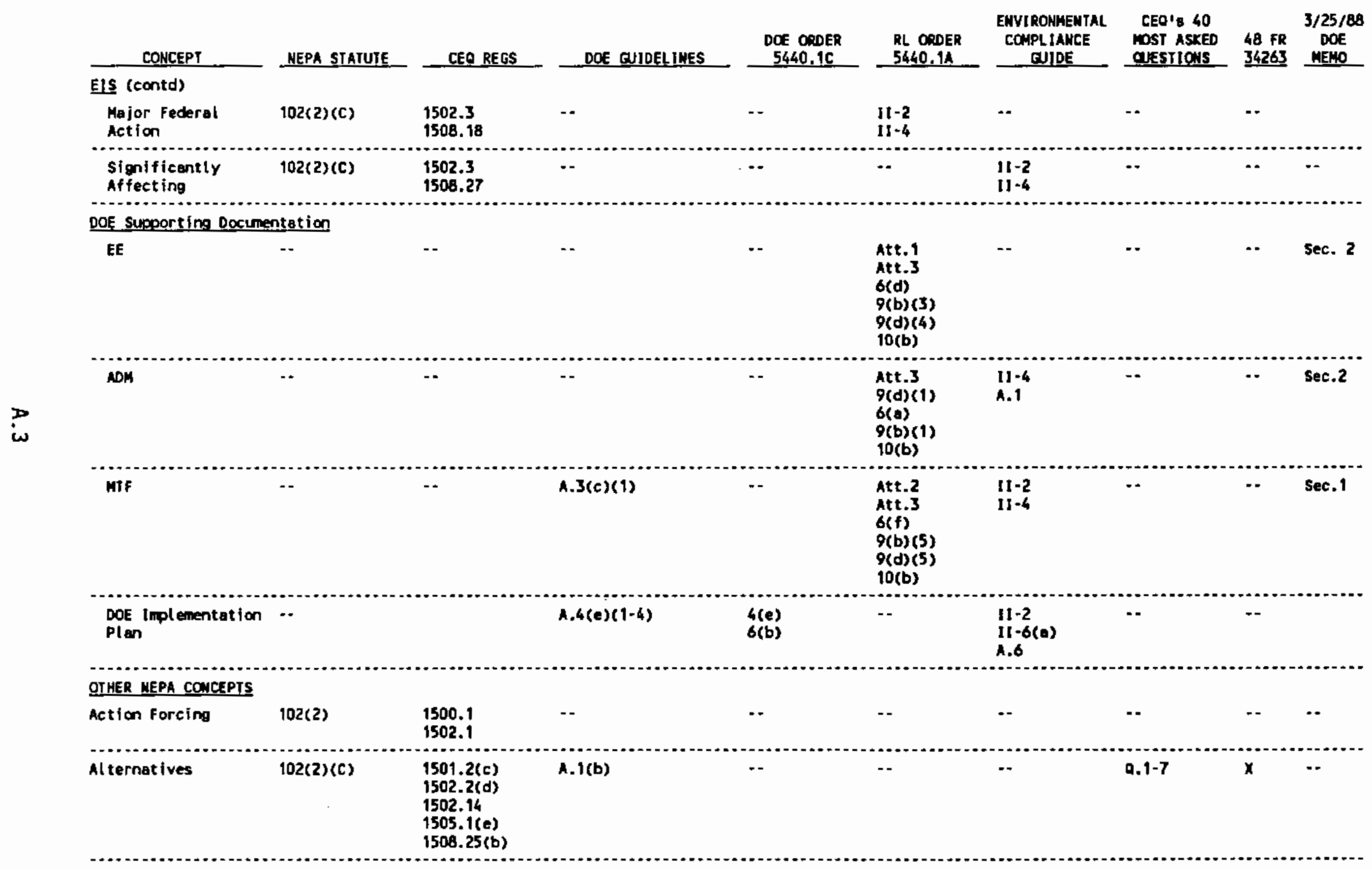




\section{IABLE A.1. (contd)}

\begin{tabular}{|c|c|c|c|c|c|c|c|c|c|}
\hline CONCEPT & MEPA STATUIE. & CEOREGS & DOE OUIDELINES & $\begin{array}{c}\text { DOE ORDER } \\
5440.1 \mathrm{C} \\
\end{array}$ & $\begin{array}{l}\text { RL ORDER } \\
5440.11 \\
\end{array}$ & $\begin{array}{c}\text { ENVI ROHWENTAL } \\
\text { COAPLJAHCE } \\
\text { GUIOE } \\
\end{array}$ & $\begin{array}{l}\text { CEO'S } 40 \\
\text { MST ASXED } \\
\text { OUESTIONS } \\
\end{array}$ & $\begin{array}{l}46 \mathrm{FR} \\
34263 \\
\end{array}$ & $\begin{array}{c}3 / 25 / 88 \\
\text { DOE } \\
\text { MEMO } \\
\end{array}$ \\
\hline \multicolumn{10}{|c|}{ OTHER NEPA CONCEPTS (contd) } \\
\hline $\begin{array}{l}\text { Cateporical } \\
\text { Exclusion }\end{array}$ & $\cdots$ & $\begin{array}{l}1500.4(p) \\
1500.5(k) \\
1501.4(a) \\
1507.3(b) \\
1508.4\end{array}$ & S.3 & $\cdots$ & $\begin{array}{l}\text { Sec.6(b) } \\
\text { Att. } .3\end{array}$ & $\cdots$ & $\cdots$ & $\mathbf{x}$ & $\sec .3$ \\
\hline Combining Docs. & $\cdots$ & $\begin{array}{l}1500.4(0) \\
1500.5(i) \\
1506.4\end{array}$ & - & $\cdots$ & $\cdots$ & - & 0.21 & $\cdots$ & - \\
\hline $\begin{array}{l}\text { Stete/local } \\
\text { Involvement }\end{array}$ & -- & $\begin{array}{l}1501.5(b) \\
1506.2\end{array}$ & $\cdots$ & -- & -- & $\cdots$ & $\cdots$ & $\cdots$ & $-\cdot$ \\
\hline Cost-Benefit & -- & 1502.23 & $\cdots$ & + & $\cdots$ & $\cdots$ & -- & $\cdots$ & $-\cdot$ \\
\hline Cumlative Inpacts & -- & $\begin{array}{l}1508.7 \\
1508.25(0),(c) \\
1508.27(b)(7)\end{array}$ & $0.3(c)(2)(111)(c)(4)$ & -- & - & $\cdots$ & - & -. & $\cdots$ \\
\hline Definitions & -- & 1508 & $\cdots$ & Sec. 4 & Sec. 6 & App.A & $\cdots$ & $\cdots$ & $\cdots$ \\
\hline Early Plaming & $\cdots$ & 1501.2 & A.1 & $\cdots$ & - & Pt. 1 & 0.8 & -- & $\cdots$ \\
\hline Judicíal Review & -- & 1500.3 & $\cdots$ & -- & $\cdots$ & 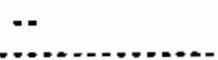 & $\cdots$ & $\because$ & $\cdots$ \\
\hline $\begin{array}{l}\text { Limitation on Action } \\
\text { During NEPA Process }\end{array}$ & -- & 1506.1 & -- & -- & $-\cdot$ & Pt. 1 & $\cdots$ & -- & -- \\
\hline Mitigation & $\because$ & $\begin{array}{l}1502.14(\mathrm{~h}) \\
1502.16(\mathrm{~h}) \\
1503.3(\mathrm{~d}) \\
1505.2(\mathrm{c}) \\
1505.3 \\
1508.20\end{array}$ & $8.3(c)(2)(111)(c)(4)$ & - & -- & $1.7-3$ & $\begin{array}{l}0.19,34 \mathrm{c} \\
39,40\end{array}$ & $\cdots$ & $\cdots$ \\
\hline NEPA Pol Icy/Purpose & $\begin{array}{l}\text { Sec. } 2 \\
\text { Sec. } 101-105\end{array}$ & $\begin{array}{l}1500.1 \\
1500.2\end{array}$ & $\cdot \cdot$ & $\sec .5$ & $\sec .4$ & $\cdots$ & $\cdots$ & $\cdots$ & -- \\
\hline $\begin{array}{l}\text { Other Enviromental } \\
\text { Reviews }\end{array}$ & $\cdots$ & $\begin{array}{l}1500.4(\mathrm{k}) \\
1500.5(\mathrm{~g}) \\
1501.7(\mathrm{~B})(6) \\
1502.25 \\
1503.3(\mathrm{c})\end{array}$ & $\begin{array}{l}\text { C.4 } \\
\text { B.3(c)(2)(iij)(c)(5) }\end{array}$ & $\sec .6(b),(c)$ & - & Parts 1,111 & $\cdots$ & $x$ & $\cdots$ \\
\hline
\end{tabular}


IABLE A.1. (contd)

\begin{tabular}{|c|c|c|c|c|c|c|c|c|c|}
\hline LOMCEPT & HEPA SIATUTE & CEQ REGS & DOE GUIDELIMES & $\begin{array}{l}\text { DOE ORDER } \\
5440.1 \mathrm{C} \\
\end{array}$ & $\begin{array}{l}\text { RL ORDER } \\
\mathbf{5 4 4 0 . 1 1} \\
\end{array}$ & $\begin{array}{c}\text { ENV1ROAMENTAL } \\
\text { COAPL IAHCE } \\
\text { CUIOE } \\
\end{array}$ & $\begin{array}{r}\text { CEO'B } 40 \\
\text { MOST ASKED } \\
\text { QUESTIOWS } \\
\end{array}$ & $\begin{array}{l}48 \text { FR } \\
34263\end{array}$ & $\begin{array}{c}3 / 25 / 8 B \\
\text { DOE } \\
\text { MEMO } \\
\end{array}$ \\
\hline \multicolumn{10}{|c|}{ OTHER KEPA COSCEPIS (contd) } \\
\hline Permit Applicents & $\cdots$ & $1508.1(d)$ & A.2 & $\cdots$ & -. & $\begin{array}{l}\text { Fig. } 1-5 \\
\text { in pt. } 1\end{array}$ & $0.9,10$ & $\mathbf{x}$ & .. \\
\hline Proposed Action & $\cdots$ & $\begin{array}{l}1502.10(e) \\
1502.14 \\
1506.2(c)\end{array}$ & $8.3(c)(2)(i 1 i)(c)$ & & & Throughourt & -- & $-\cdot$ & -. \\
\hline Public Involvement & $\cdots$ & $\begin{array}{l}1501.4(e) \\
1503.1(a)(3) \\
1506.6\end{array}$ & $A .4(c)$ & -- & $-\cdot$ & $\begin{array}{l}A .10 \\
j i-6(b)\end{array}$ & $0.29,37,38$ & .. & - \\
\hline scoping & $\cdots$ & $\begin{array}{l}1500.4(b) \\
1500.4(b) \\
1501.1(d) \\
1501.4(d) \\
1501.7 \\
1502.9(d) \\
1502.4(d) \\
1506.8(b)\end{array}$ & $\begin{array}{l}0.2(0)(1) \\
0.4\end{array}$ & $\because$ & -. & $\begin{array}{l}1.6(b) \\
1 t-6(0)\end{array}$ & 0.13 & $\cdots$ & .. \\
\hline tiering & $\cdot-$ & $\begin{array}{l}1500.4(i) \\
1502.4(d) \\
1502.20 \\
1508.28\end{array}$ & $\begin{array}{l}8.1 \\
8.2(\theta)(0)\end{array}$ & - & .. & $\cdots$ & 0.24 & $x$ & $\cdot \cdot$ \\
\hline Time Limits & $-\cdot$ & $\begin{array}{l}1500.5(e) \\
1501.1(e) \\
1501.7(b)(2) \\
1501.8\end{array}$ & c.3 & $\cdots$ & -- & $\begin{array}{l}11-2 \\
11-4\end{array}$ & $\because$ & $\cdots$ & $\cdots$ \\
\hline
\end{tabular}




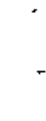




\section{APPENDIX B}

DOE NEPA GUIDELINES, 52 FR 47663, DECEMBER 15, 1987 


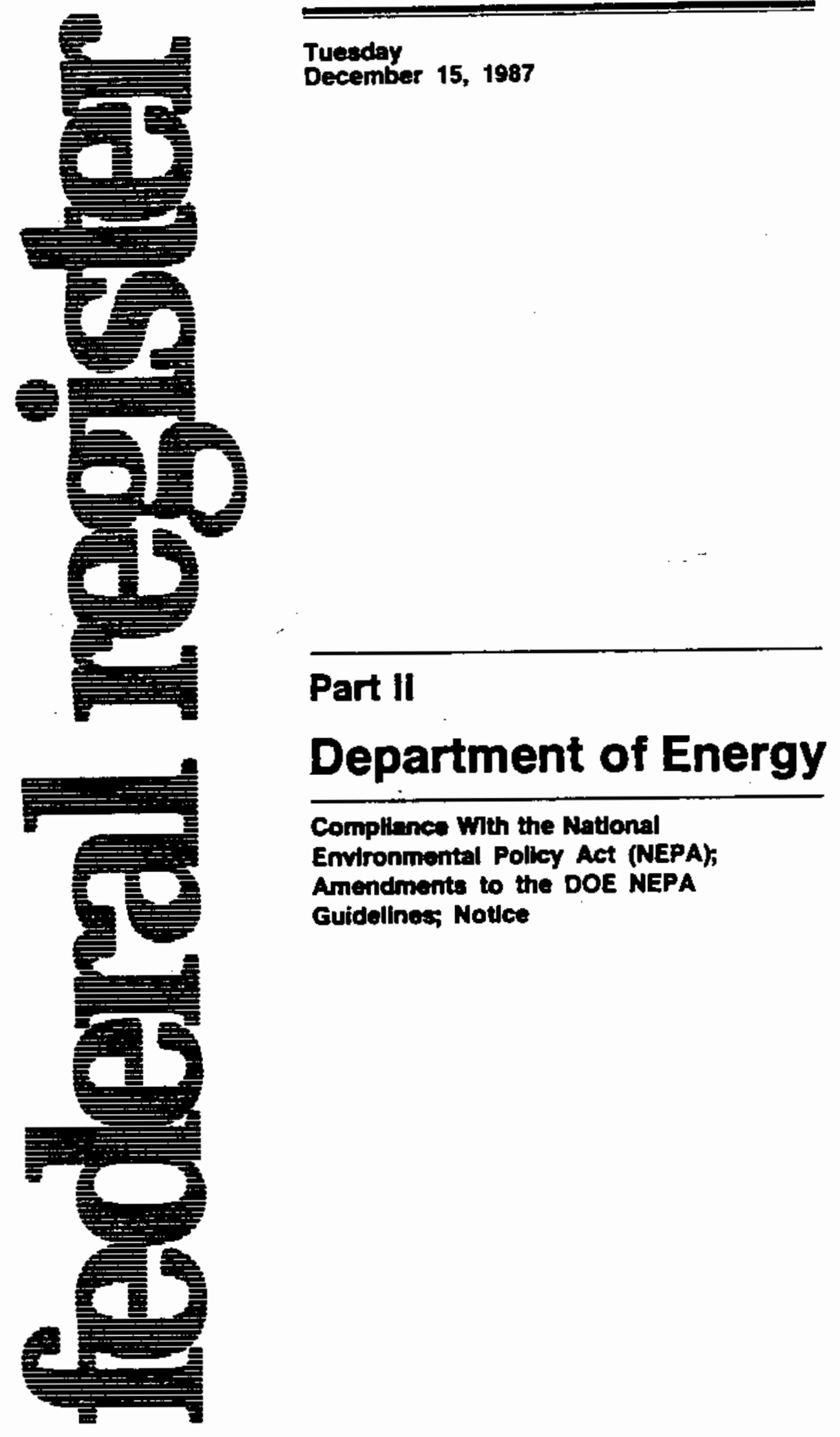

B. 1 


\section{DEPAATMENT OF ENERGY}

Cormpthance With the Natlonal Environmentel Policy ACt (NEPA) Amendments to the DOE NEPA Guideline:

Acever, Department of Energ;. actow: Notice of amendments to and repullication of the Departenent of Enersy's NEPA guidelines.

summarr: The Department of Energy' is amending Section D of its guidelines for compliance with the National

Environmenta! Policy Act (NEPA) hy udding eight new typichl classes of uctions. by modilying four existing typical classes of actions, and by deieting one typicsl class of actions, as proposed on February 25. 1985. \{50 FR 76 ? published on March 28. 2880 , (45 FR 20a94) and subsequently has been amended on Febnuary 23. $18 \mathrm{Ba}$ ( $47 \mathrm{Fh}$ $7976)$. January 6, 1943. (48 FR 685). and fanuary 7.1987, (52 FR 659). Sections $\Lambda$ $B . C$ and amended Section $D$ of the NEPA guidelines are republished in their entircly.

EFFETIVE DATE: December 15. 1960. FON AURTHEA WFOMEATION COMTACT. Carol Borgstrom, Acting Director. Ofrice of NEPA PTojett Assistance EH I-25. Ronm 3E-080 U.S. Department of Encrgy, 1000 independence Avenue. SW. Wrushington. DC 20585 (203) 5864000.

Henry Garson. Esq. Assistant Ceneral Counsel for Environment. CC-11. Room 6A-113 U.S. Department of Energy' 2000 Independence ävenue. SW.. Vishington DC 20595. \{002\} 580G47,

Supprementawy imfonemariom; On March 28. 1980, the Department of Energy (DOE) published in the Foderal Register (45 FR 20a94) linal guidelines for comptiance with the Nationsl Environmental Policy Ac1 [NET $A$ ], us required by the Council on

Environmental Quality (CEQ) regulations [40 CFR Parts 1500-1500). Section D of the Department's guidtitines identifies typical classes of $\mathrm{DOE}$ actions: (1) which normally do not require either an environmentol assessment (EA) or an envi ronmental impact statement (EIS). i.e., calegorical exclusions. (2) which normally require an EA but not necessarily an ESS. and (3) which noms lly require on EdS. These clusses of actions were identified purtuant to CEQ regulations (40 CFR $1507.3[(\mathrm{~b})(2)]$.

A notice of propoced amendments to Section D of DOE: guidelines wiss published on February 25. 1985. [50 FR
7629). The proposed amendments reiated primarily to activities of the Department's Power Marketing Administrations, and proposed adding eight new typical classes of actions. modifying four existing typical ciasses of actions. and deluting one typical class of actions. Specifically, the proposed amendments were the sddition of meven and modification of two categorical exclusions, the addition modjfication and deletion of classes of actions which namully require an EA. and the modification of one class of actions which nomally requires an EIS.

Publication of the proposed amendments commenced a Jo-day public comment perioc. No comments were received. The firal amendments at stated below are essentially the same as the proposed amendments. Certain clatifying changes huve been made. as noted.

The following categaricol exclusiona, i.e.. actions which normally do not individually or cumblativeiy have a significant effect on the quality of the human environment and therefore for which neither an EA nor an ElS is required. have been added:

1. Construction of tap lines (defined a usualiy being iesa than 10 miles in length) which are not (or the integration of major new sources of generation into DOE' s main transmission aystems, and where sich aclions do not impact environmentally senaitive sreas such as archueological vites, critical babitats. floodplains. and wetlands. (Note - This has been modified from the amendment proposed in $50 \mathrm{FR} 7629$ to make it clear that the parenthetical information is a definition of "tap lines" and is not a transmission line iength criterion, and to use a length that is more in keeping with the normal maximum length of $a$ tap line. i.e. 10 miles instead of $B$ miles.

2 Construction of microwave and radio communication towers and associated facilities where such ections do not impact environmentally eonsitive areas such as archaeological sites. critical hubilats. foodplains, and wetlands. und where such octions do not prejudice future site selection decisions for substations or other transmission focilities. (Note - The words "and radio communication" have been udded to the smendment proposed in 50 FR 7 B29 to include radio towern, which have entirontrental impacts similar to those of microwave towers.)

3. Disposal of real property by the DOE through the General Services Administration where the planned land use is to remain unchanged.

4. Financial and technical assistance to individuals (builders. ownert. designcrs) and to state and local governments to promote energy efriciency in new structures built in compliance with appiicable, duly adopted building codes.

5. Small scale reseetrch and development projects designed to demonstrate potentiel electrical energy conservation associated with residential/cornmertial buildings. appliance/ equipment efficiency standards, and manufacturing and industrial processes (e.8. insulation effectiveness. tighting effieienties. appliance efficiency ratings. and deveiopment of manufacturing or indus trial plant efficiencies).

6. Activities urdertakes to restore existing fish and wijdlife facilities. including minur habitat improvements or improvements to txiating fish passage facilities ut existing dams or diversion canals.

7. Power marketing services including slorage, load ahaping, seasonal exchanges, or other similiar activities where the operations of hydroelectric projecta remain within established constraints and which do not alter the environnental status quo. (Note - The term "load factoring" in the amendment proposed in 50 FR $; 629$ has been replaced by the term "losd shaping".]

The addition of the new categorical exciusion number 1 above makes it nectias; to make a conforming change. as proposed to an existing typicsl cless of setioas narmally requiring st. EA. The typical cluss of ections "Construction of new service facilities such os tap !ines and substations," has been modified to read es follows: "Constraction of new substations."

The following typical class of actions has been added to those which normally require EAs but not necessarily EISs: Execution of marketing plans or allocation plans for the long term allocation (grester than 1 year) of existint or excess power resources to customers who can receive the resources over existing transmission systems. (Note - This bas been modified from the amendment proposed in $50 \mathrm{FR}$ 7629 to $\mathrm{r}$ hect the focus of environmental review on marketing or allocation plans rather than on individunl coniracts executed under approved plans. The allocation of power reyources to customers in a manner differing from existing contractual arrangementa is already an existing class of actions tequiring an EA. The lerm "lacilities" in the amendment proposed in 50 FR 7629 has been replaced by the term "systems".)

The existing categorical exclusion "Execution of contracts for the short lerm or seasonal allocation of excess 
power resuufces 10 customers who citn rerpive these resources over existing transmission systems," is modified as follows: Execution of contracts. mariketing pians, or tliocation plans for the shor: lerm or seasonal allocation (less thal 2 year) of existing or excess power resources to customers who can ruceive these resources over existing transmission systems. (Note; This has been modified from the amendment propused in 50 FR 7629 in include marketing or allocation plans as weil as individual contracts executed under approved pians. The allocation of power resources to customers in a manner differing from existing contructual arrangernents is already an existing class of actions requiring an EA.)

The existing class of actions nomully requiring an ESS. "DOE actions which cause energy conservation on a substantial scale," is modified as follows: DOE actions which cause enerzy conservation on e substantial scale. including those where effects are primarity on the indoor environment [e.g. induor air quality]. (Note: This has been modified from the amendment proposed in 50 FR 7629 for clurifiution.)

The existing cutegorical exclusion "Minot uduitions to a substation. transformer additions, or chenges in transformer assignments that do not affect the area beyond the previously developed substation area," is modified as foilows: Minor substation modificetions, which do not involve the construction of new transmission lines or the integration of a mujor new resource, and where such actions do not impact environmentaily sensitive areas such as archaeotogical sites. criticul habitats. Moodplains, and wellands. [Nole: This modification is identica] to that proposed in 50 FR 7029.)

As a result of the above modification. the following typical class of actions normuly requiring an EA but not necessarijy an ElS has been deleted: "Modificationg of existing focilities (e.g." subsintions. storage yords\} where impacts extend beyond the previously developed facility area." Thus. an EA is not autamatically required for facility modifications thit extend beyond the previously developed area. However. if the limiting criteria in the categorical exclusion cannot be met (if the action involves construction of new

transmission lines or the integration of a major new source or if there will be impects in environmentally sensitive areasl. then an $F A$ would be reyuired.

DOE his consulted with the Council on Environmental Quulity (CEQ) rogarding these amendments, in accoidance with to CFR 1507.3. CEQ had no abjection to the proposed amondments. Therefore, DOE has adopted these amendments to Stction D of its NEPA Guidclines, eltective immediately.

The Depurtment's NEPA Guidelinus are republished as follows in their entirety. The republication incorporates amendments to the original Section $D$ [45 FR 20094. March 28. 1980) which were finalized on February 23. 1982. [47 FR 7976], January \&. 1963. [48 FR 695], Japuary 7, 1997. (52 FR 659), and by this notice. Sections A. B. and C of the Guidelines are reprinted as published in 45 FR 20044 with the exceptions that [1] responsible DOE uffices have been changed as apprupriate and (?) the list of other environmental laws that are coordinated with the NFPA process has been updated.

Isaued in Washington. DC on November 19. 1987.

Mary L Walket.

Assistont Secretary for Environnlent, Sufity nnd Heallh.

\section{DOE NEPA GUIDELINES}

Pupose

Section A - hiEPA and Agmcy PIencho

P:uragraph A.1 DOE Procesa f 10 CFR 1501.2]

Piragriph A.2 Appticant Processes |W0 CFR isol.2(d)

Paragraph A.J Whethor to Prepure an Environmental tmpact Statement [\%0 CFR 1501.4. 1508.34h) (2), and 1504.4

Parugraph A.4 Scoping $j+0$ CFR 1S01.71

\section{Section B - MEPA and Apmcy}

Dentaionmaiding

Parapraph B.1 DOE Decisionmuking [40 CFR 1505.1 !

Paragtaph B.2 Coneral Procalures

Paragraph B.3 Specific Prueedures

Section C - Other Acquiniments of MEgA

Paragraph C.1 Access to NEPA Ducumenis [10CFR 150t.3|c||]

Pirugraph C_2 Supplemuntal Stutements |40 CFR 1502.9 ( $\mathrm{d}$ )

Pumgraph C.3 Revisiuns of Time Periods $\{$ to CFR 1507.3!d)!

Patragraph C.t Cuordination With Other Environmentil Laws |40 CER 1502.25

Paragraph C.5 Status of NEPA Actions 1 to CFR 150R.6|et]

Paragraph C.6 Oversight of Agency NE.PA Activities [4 40 CFR 350T.2(1)]

Paragraph C. 7 Compliance

Purazraph C.B Revisiong to the Guidelines

Section D - Typical Cluatsen of Action

\section{Purpose}

The purpose of these guidelines is to provide procedures which the Department of Enurgy (DOE) will apply 10 impltment the Cuuncil on Environmental Quality \{CEQ! regulations for compliunce with the
Nutional Environmental Pulicy Act (NEPA). The CFQ regulitions ase codified at 40 CFR Parts 1500-1508. The guidelines are issued pursuant to and are to be used onily in conjustction with the CEQ regulations.

The guidelines are intended for use by ail parsons acting on behalf of DOE in catrying out certain provisions of the $C E Q$ regulations. They are not intendit. however, to create or enlarge any procedural or substantive rights agitinst DOE. Any deviation from the gujdelines must be soundly based and must have the advance approval of the Under Secretary of DOE.

\section{Soction A - NEPA and Aoency Planning}

\section{DOE Process}

The CEQ regulations (40 CFR 1501. If require that: "Agencies shall integsat? the NEPA process with olher planning it the earliest possible time to insure thit plonning and decisions reflect environmentoi values. to avoid delays later in the process. and to head off potential connicts."

To implement this requirement DDF. will:

(a) Review predimingry inlersal progrum planning documents. regulalory agenda. draft legislation. builgetary materials and other developing DOF. proposais, to ensure the proper integration of the NEPA process:

[b] Incorporate into its early plunning processes a cereful considerition of: [i] The potential epvironmental consequences of jts proposed aclions. and (ii) appropriate altemative courses of action:

(c) At the earliest possibie time. in accordance with paragraph $A .3$ hercin. Jetermine whether an environmenta! assessment [EA] or an environmentis! impact statement [EIS] is required.

\section{Applicant Processes}

With respect to applicant processes. the CEQ regulutions (40 CFR 150t.2|ل|) require agencies to:

"(d) Provide for cases where actions are planned by private applicants or other non-Federa! entities beJore Faderal involvement so that: (1) Policies or designated staff are available to advise potential applicants of studics or ather information fortseeabiy requircd for loter Federal action.

(2) The Federal inency consults eirly with appropriate S1ate and local agencies and Indian tribes and with inlerested privite persons ind organizalions when its own involven'sn is reasonably foreseeable. 
[3] The Federal agency commences its NEDA process at the eariliest possible time."

To inolement this reutimenen:

(a) Applicants ias a DOE lease. permit, license. certificate, financial assistance, aliocation. exemntion o: similur uclion are experted to:

(1) Consult with DOE as eariy as pussible in their planning processes to obtain guidance with respect to the appropriale level and scope of any sludies or environmental iniomation which DOE may require to be submitted as narl of or in support of their application:

(2) Conduct studies which are decned necessury and appropriate by DOE to detemine the impect of the proposed action on the quality of the human environment:

(3) Consult with sppropriate Federal. regionat. State and loca! zgencies and other potentially interested parties during the preliminary planning stuges of the proposed action to ensure thet environmental factors inciuding permitting requirements are identified:

(4) Submit applications for all required Fetieral. regional. State and local permits or approvats as early as possibie:

(5) Notify DOE as early as possibie of other Federal, regional. State. Jocal and Indian tribe actions required for project completion in order that DOE may coordinate the Federal environmental review, and fulfill the requirements of 40 CFR 1506.2, regarding elimination of duplitation with State and locel procedures. as appropriate:

(6) Notify DOE of privite persons and organizations interested in the proposed unciertaking, in order thet DOE can consult. as appropriate, with these parties in accordance with 40 CFR 1501.2(d)(2);

(7) Notify DOE if, prior to completion of the DOE environmental review and decisionmeking process, the applicant plans or is about to take an action in furtherance of an undertaking within DOE's jurisdiction which may meet either of the ctiteria set forth at 40 CFR 1500.1/a).

(b) Upon receipt of an application, or earliet if possible. DOE will:

[1] fnitiate and coordinate any requisite environmental analyses in accordance with the requirements set forth at 40 CFR 1508.5;

(2) Determine. in accordence with paragraph A.j herein- whether an EA or an EIS is required: and

(3) Estabtish time timits for the NEPA process when requested to do so by an applicant.

(c) For major categories of $\mathrm{DOE}$ uctions invoiving a large number of applicarts. DOE may prepare generic guidelines describing the level and scope of environmental iniormation expected from the applicant and wit make such guidelines availabie to applicants upon request.

(d) For DOE procrams that frequently involve another agency or agencies in reiated decisions subiect to NEPA, DOE will cooperate with the other agencies in deveioping environ-mental information and in delemining whether to prepare an EA or an ElS. Where sppropriate and acceplabie to the other agencies. DOE will develop or cooperate in the development of interagency agreements to lacilitale cuordinstion and to reduce dejoy and duplication.

3. Whether to Prepore on Environmental Impoet Statement

The CEQ regulations (40 CFR 1501.4) require the Federal acency, in dejermining whether to prepare an EIS, to:

"i(a) Determine under its procedures suppletnenting theae regulatuono (veseribed in Section 1500.3) whether the proposal is one which:

11) Normally requires an environsental impact statement. ar

(2) Normaliy does not require either an environmentai inpact stalement or an envrotimartal asientment feriegorieal exclumion).

(b) If the proposed ection is not covered by paragraph (a) al this seation propare an environmental aweadment (Section 25ng.9)."

To implement this requirement and the requirements contajned at $40 \mathrm{CFR}$ 15073(b)(2):

(4) DOE has (in Section D), identilied typical classes of DOE action:

"(i) Which normally do require environtmental impace ststements.

(ii) Which normally do not require either an environmental impact watement of an environmental ansesement [calegorics] exclusions (Section 1500.4)).

(iii) Which nomblly require tenvisontmenta assessments but nol neceusarily envirommental impact statements."

(b) DOE will review individual proposed actions to determine the appropriate level of NEPA documentation required where:

(1) The proposed action is not encompassed within the categories of Section D.

(2) The proposed action is encompassed within the chtegories of Section D. but DOE believes that the calcgorization is not appropriale to the individual proposed action.

(3) Public comment received on or relating to a proposs included within the categories of Section D raises a substantial queation regarding the cotegorization. (c) DOE will, in conducting the revicus of paragraph (b) above. either.

(1) Determine thot neither an EA nor an EIS is recuired wingte it is clear that the provosed action is not a major Fuderal action significantly affecting the quaiity of the human environment. lit such cases, a briẹ memorandum may be prepared explainirg the basis for that determination);

(2) Prepare an EA where it is unclear whether an EIS is required: or

[3] Proceed directly to EIS preparatiun where it is clear that an EIS is required.

(d) DOE may add actions to or remore actions from the categories in Section D bused on experience gained during implementation of the CEQ regulations and these guidelines.

4. Scoping

The CEQ regulations (40 CFR 1501.7) require:

... - an early and oper process for determining the ocope of issues to be addressed and for identifying the stipnifican isauce reiated to a proposed action."

To implement this requirement, DOE wilt.

(a) As soon as practicable after a decision to prepare an EIS. publish in the Federal Register a Notica of Intent (NOI) to prepare an EIS in accordance with 40 CFR 150n.7. However, where

DOE finds that there is a lengthy period between DOE's decision to prepare an ELS and the time of actual preparation. DOE may instead publish the NOl at a time sufficiently in advance of preparation of the draft EIS to provide reasonable opportunity for interested persons to participale in the EIS preparation process:

(b) Provide additional dissemination of the NOI in accordance with $40 \mathrm{CFR}$ 1506.6:

(c) Through the NOL invite comments and suggestions on the proposed scope of the EIS including environmental issues and alternatives for consideration in the preperstion of the draft ElS and invite public paricipation in the NEPA process except where there is an exception for classified proposals pursuant to $40 \mathrm{CFR} 1507.3$ (c) and paragraph $\mathrm{Cl}$, hereir The comment period for the NOI will nomally be 20 days. To the extent practicsbie, DOE may consider comments received after the close of the designated comment period on the NOl in preparing the draft EIS

(d) If a scoping meeting is to be held provide notice of the meeting in the NOI at least 15 days before the meteting.

(c) PTepere and use an EUS implementation pian to record the results of the acoping process and to 
provide guidance to DOE for the preparation of an EIS.

(1) The EIS implementation plan will be a brief document and will contain:

(i) Iniormation to address the provisions of 40 CFR 1501.7(a)(2). [3], (5), (B). and (7):

(ii) A detailed outline of the ErS:

(iii) A description of the means by which the EIS will be prepared. including the nature of any controctor assistance to be used.

(2) The EIS implementation plan may also cantain:

[i] Target page limits for the Els; (ii) Target time limits for EIS prepuration: [iii) An a!location of assignments amons DOE and cooperating agencies.

(3) DOE will complete an EIS implementation plan as soon as practicable after the close of the designated comment period an the NOI or after a scoping meeting. if one is held. whichever is later.

(4) DOE may revise the implementation plan, as necessary during EIS preparation.

\section{Section B - NEPA and Agoney}

Decisionataking

\section{DOE Decisionmaking}

The CEQ NEPA regulations $1+0$ CFR 1505.1] require that agercies adopt procedures to ensure that decisions are made in accordance with the policies and purposes of NEPA.

To implement this CEQ requiremenI, this section designates the major decisionmaking proceases for DOE's principal programs and provides procedures to assure that tha NEPA process corresponds with the decisionmaking processes. These processes are designated as policy level decisionmaking. program level decisionmaking, and project level decisionmaking. The procedures consist of general procedures applicable to all DOE decisionmaking processes followed by specific procedures appliesble to the individual decisionmaking processes.

The decisionmaking structure designated herein is consistent with the CEQ tiering concept (40 CFR 1502.20). which provides for focusing on the actunl issues ripe for decision and eliminating repetitive discussions of the issues already decided. Accordingly. environmental documents prepered for policy level decisions will nomally focus on broad issues and will provide the foundation for subsequent program and project environmental decuments. Environmentai documents prepared for program levej decisions will narmslly focus on rarrower issues than at the poticy level and may aummarize and incorporale by reference discussions cuntained in any relevant policy level environmental document but should not repeat the discussion of issues already decided at the policy level of decisionmaking.

Similarly, environmental documents prepared for project level decisions wil normaliy focus on issues specific to the proposed project and may summarize and incorporate by reference discussions contained in any broader environmental documents but should not repeat the discussion of issues decided at bigher levels of decisionmaking.

\section{General Procadures}

(a) The following general procedures tepply to all DOE decisionmaking processes. DOE wilk:

(1) Al the earliest possible time in the decisionmaking process: (i) Identify and evaluate environinental factors and appropriate altemative courses of action, and (ii) determine in accordance with paragraph A.3 herein the appropriate level of environmental review document required.

[2] Commence preparation of the relevant environmental document as close as possible to the time that DOE begins development of or is presented with a proposal (40 CFR 1SC8 23), and complete the document in advance of final decisionmaking.

(3) During the development and consideration of a proposal and the relevant environmental document. review other DOE planning and decisionmsking documents to ensure that alternatives (including the proposed action) to be conoidered by the decisionmaker are encompassed by the range of altematives in the relevant environmental document.

\section{(4) Cireulate the relevant} environmental document or summury thereof with the proposal and other decisionmaking documents through DOE's internal review processes to ensure that DOE officials use the snvironmental documents in making decisions and that the decisionmaker consider the aitematives described therein.

(5) Where an ElS is prepared. publish the record of decisiun ( +0 CFR 1505.2) in the Federal Regiater and make it availathle to the public as specified in 40 CFR 1506.6 except as provided in puragraph C.l. For the purposes of 10 CFR 1506.1. the record of decision will be deemed issued upon signature by the appropriate DOE officiai.

(6) Utilize the tiering concept in accordance with 40 CFR 150220 and t508.2B to the fullest extent practicable.

\section{Specific Procedures}

(a) Policy-level-decisionnoking. At this kevel of decisionmaking. DOE. is deciding on broad strategies to achicve energy goals such as conservation. development of new resources and use of more abundant resources. Policy level decisions mey, for example, be represented by proposals for legislation or by formal statements of national energy poilicy.

(1) For legisiative propositls. DOE will: Identify and evaluate relevant environmental issues and reusopable alternutives. and make a delermination regarding the need to prepare an environmental document during the propesal formulation and early drafting stages; and. nomally prepare, considur. and publish any required environmenlal document in connection with the aubmiltal of a proposal to Congress. except as may be provided in 40 CFR 1506.8.

(2) For formal statemerts of national energy policy DOE will: Initiste impiementation of the appiicable gencrul procedures specilied above during the analysis phase of policy development; and will prepare, considter, and publish any requited environmental document in advance of policy adoption for those policies that will result in or substantially alter DOE programs.

(b) Prognam-leval-decisionmaking. At this ievel of decisionmaking. DOE is deciding on a variety of approsches to implement apecific policies of statutory guthorities. Program level decisions ure generully represented by the

advancement of an energy iechnology program, the issuance of program regulations. or the adoption of a program plan.

(1) For energy technology research. development, demonstration and commercialization programs. DOE will: initiate the applicable general procecures apecified above coneurrent with program initiation: and. if required. prepare the relevant envimonmental document when environmental effects can be meaningfully evaluated. When required. the relevant environmertal document would normally be prepurec in advance of a decision to proceed with the deveiopment phase of a reseurch. deveiopment, demonstrstion, and commercialization progra $m$. Nevertheless. DOE will consider the following factora throughout the program in determining the necessity and appropriate timing of the relevant environmental document: (i) The significance of the environmental impacts of the technology. if applied. un the quality of the human environment: 
and (ii) The extent to which continued investment in the new technology is likely to cause the program to reach 8 stage of investment or commitment to impiementation likely to determine sulsequent development or restrict Jater ultermatives.

[2] Fot programs that ane implemented by regulutions. DOE wili initiato implementation of the applicabie gencrai procedures specified ubove dituting eardy regulation drafting stages. Pubticution of a draft ElS. if required. will normally accornpany publication of tle proposed regulations and will be available for public comment at any hearings held an the proposed repulations. The draft ElS need not iccompeny natices of inquiry or advunte notices of proposed rulemuking intended to gather information during early slages of regulation development. The relevant environmental document. with cumments and responses, will be included in the administrative record. In accordunce with 40 CFR 1506.10(b)(2) final rulemakings promulgated pursuant 10 the Administrytive Procedure Act may be issued simultaneously with pubication of the nolice of the avaitability of the final ElS.

(3) For programs that are not inciuded in paragraphs (1) or (2) und that are implemented by a formal program plan. DOE will: initiate implementation of the applicable general procedures specified above concurent with program plan furmulution: and, if required, prepare the relevant environmental document when the environmental effects of the proystam can be meaninglully evalualed If an EIS is required. it will be prepared. considered, atid publishedl and the tequisite record of decision issued beiure taking an action thal would have un adverse environmental impuct or limit the choice of reusonable allemalives excrpt as provided in $\mathbf{4 0}$ CFR 1506.1(c)

(c) Pryject larel decisionmaking. At this level of decisionmakine. DOE is deciding on specific actions to execute a program or to perform a regulalory responsibility. Project level decisions are generally sepresented by the approval of projects. by the approval or disapproval of applications, or by the decisions on applications rendered in idjudicalory proceedings.

(1) For projects that are underaken directly by DOE including projects involving the sole source procurement of a sile and/or process. DOE will: initiate implementation of the applicable generai procedures specified above concurrent with project concept deveiopment: and if required prepare, consider, and pubitish the relevan! environmental document before making u go/no-go decisian on the project. in addition. if a DOE project requires preparation of an EIS. DOE will not take an action concerning the project which would heve an adverse environmentul effect or which would timit the choice of rensanyble alternatives until the required record of decision is issued.

(2) For major syetem ecquinition projects invoiving selection of sites and/ or processes by competitive procurement. DOE will:

(i) Require that environmental date and analyses be subanitted as a discrele part of an afferor's proposal. The level of detail requised for environmental duta and snalyses will be specified by DOE for each applicable procurement action. The data will be limited to those reasonably available to offerors.

(ii) Independently evaluste and verify the accuracy of enviroamental dato and analy'sec submitted by offerors.

(iii) For propasals in the competitive range. prepare and consider before the selection of sites and/or procesues an environmental impuct analysis in accordunce utth the following:

(a) In order to comply with 18 U.S.C. 1905 which ptohibits DOE from disciosing business, confidential of trade secret information. the environmental impact analysis will be subjest to the conlidentiality requirements of the competitive procurement process and therefore exempt from mendatory public disciosure.

(b) The environmental impact analysis will be based on the environmental data and analyses wubnitted by offerors and an supplemental information developed by DOE as necesary for a reasoned decision.

(c) The enviranmental impact anglysis will focus on environrivental insues that are pertinent to secielea on proposals in the competitive range and will inciude:

[1) A briel discunaian of the purpase of each proposal including any aile ar procese veriation having environmentel implications.

(2) For each proposal. a diecuesion of the salient characteristics of the proponed sites and/or processes us well as altemutive sites and/or processes reasonably available to the offeror of to DOE

(3) A brief comperattive evaluation of the environmenial impacts of the proposels. This ovaluation will focus on simificent environmental ianues and ciearly identify and define the comparative environmental ments of the proposals.

(4) A discussion of the environmental impacts of each proposeal This discutsion will addres direct and indirect effects, short-term and longterm effects. proposad mitigation measures. adverge eflects which cannot be avoided. areas where importint environmental iniormation is incompiste or unavilable. unregolved enviranmeata! issues. and practicaule mitigating messures not included in the. proposal

(5) To the extent known for each proposal, a list of Federal. State. and locel gavernment permits. Jicenses. and approvals which must be obtained in implementing the proposal.

(iv) Document the cungiderution given to environmental factors in a pubiicly aviilable selettion statement to record that the relevasl environments! consequences of reasonable alternatives have been ovalualed in the selection procesc. The selection statement will not contain business. confidential, trade secret or other information the disclosure of which is prohibited by 18 U.S.C 1905 or the confidentiality requirements of the competitive procurement process. The selection statement will be filed with the Environmental Protection Agency.

(v) If the relected sites and/or proceases are likely to have gignificant eflects on the quality of the buman environment. phase subsequent contract work to allow publicly available EIS' s 10 be prepared, considered and published in full conformance with the requiremento of 40 CFR Parto 1500-1500 and in advance of a go/no-go decision.

(3) For projects that involve applications to DOE Ior [inancia] aesistance or applicalions to DOE for \& pemil, license, exemption allocation or similar regulatory action involving informal administrative proceedings, DOE will: apply NEPA early is the process in eccordanes with $40 \mathrm{CFR}$ 1501 2(d) and paragroph $A .2$ herein: commence preparation of the rclovant environmental document. if required no later than immedistely after applications are received and in accordance with the requirements not forth at 40 CFR 1500.5; and consider the relevant environmentul document. if nne is prepared, in decisions on the application.

(4) Fot actions that involve adjudicatory proceedings, excluđing judicial or adminintrative, civil, or criminal enforcement actions, DOE will: normally prepare, consider and publish the relevant envirotumental documenh if required, in advance of a decision, and include the document in the formal record of the proceedings. If an ElS is required, the drafi EIS will normulty precede preliminery atait recammendatione. and publication of 
the final EIS witl normally precede final staff recommendations and that portion of the public hearing related to the EIS. The ElS need not precede preliminary hearings designed to gather information for use in the ElS.

\section{Section C - Other Requirements of MEPA}

\section{Access to NEPA Documents}

The CEQ NEPA regulations ( 10 CFR

1507.3[c)] allow an agency to develop criteria for limiting public aceess 10 environmental documents which involve classified information. This section provides the DOE policy for addressing classified infermation as well as poicy for aduressing confidential information.

Classified or confidential information is exempted from mandatory public disciosure by Section 552[b] of the Freedom of Information Act (FOIA] [s U.S.C. 552\}. Section 2004.10 (b) of DOE's regulations inplementing FOLA (10 CFR Part 1C041, and 18 U.S.C. 1905. Public access to such information will be restricted in accordance with such regulations and applicabie statutes.

All NEPA documents (as defined at to CFR 1508.10), the Els implementation plan, and the record of decision are subject to the mandatory public disclosure requirements of FOLA and the DOE regulations implementing FOIA except documents which are determined. in accordence with the applicable statutes and reguiations, to contain classified or confidential information. DOE will determine the trealment of documents costaining classified or conididential informotion on a case by case basis in accordance with the requiremants of DOE' FOLA regulations and the epplicnble statutes.

Wherever possibic, the fundamental policy of full disciosure of NEPA documents will be foilowed In some cases, this will mean that clasoified of confidential inlormation may be excised prepared as an appendix or otherwise segregated to ailow the nelease of the nonsensitive portions of a doeument

\section{Supplomental Statements}

(a) II required. DOE will prepare. circulate, and file so supplement to a draft or final ESS. in accordance with 40 CFR 15029(c). However. where it is unclear whether an EIS supplement is required DOE will prepare en analysis which provides sulficient information to support a DOE determination with respect to the criteria of 10 CFR 1502.9\{c

(i) and (ii). Based on the analysis. DOE will determine whether to prepare an EIS supplement. Where DOE determines thot an ElS supplement is not required. DOE will prepare a brief memorandum which expiaing the besis for that determination.

(b) When applicable. DOE will incorporste an ElS appiement or a brief memoryndum and suppotting analysis into any rełatod formal administrative record prior to making a final decision on the action which is the subject of the EIS suppiement or analysis.

3. Revisions of Tine Periods

The CSQ regulations (40 CFR 1507.3 (d)). allow agencirs to provide for periods of time other than those presented in 40 CFR 1300.10 when necessary to comply with other specific stotutory requirements.

Certain circumstances, such as statutory deadlines. may require that the periods established in 40 CFR 150B.10 for the tining of DOE NEPA actions be altered. If DOE determines that in ordar to comply with specilic requirtements of other statutes, such revisions are necessary, a notice of the determination will be published in the Federal Register. This notice will briefly provide the reason for such altarations and contain information on the revised time periods. Related notices of substantive action. if appliczole. may be published jointly with noticea publighed putsuant to this paragraph.

\section{Coordination With Other Environmental Law}

The CEQ regulations ( +0 CFR 1502 ns) provide for integrating the NEPA process and other environmental requirements.

To the fullest extent possible. DOE will:

(a) Coordinate NEPA complisunce with other environmental review requirements including those under the Cleen Air Act, the Clean Water Act, the Coostal Zone Management Act, the Endtingered Species Act. the Fish and Wildiife Coordination Act, the Wild and Scenic Rivers Act, the National Historic Preservation Act. Section 13 of the Federal Nonnucisar Resenrch and Development Act, the Marine Protection.
Resparch ind Sanctutiries Act. the Resoutce Conservation and Recovery Act, the Comprehensive Essironmental Response, Compensation. and Liability Act, and other Acts. as deamed appropriale by $\mathrm{DOE}$

(b) Determize the applicability of other environmental requitements early in the planning process lo ensure compliance and to avcid celays.

(c) In addition to the information required by 40 CFR 1502.25 (b). include in draft and finai EISs plans and estimaled chedules for compliance with other applicible environmental roview requirements.

(d) Use the televant NEPA document to support the fuifillment of the review and documentation requirements of other environmental statutes and regulations, and to report the status of compliance with these other environmental authorities.

\section{S. Status of NEPA Actions}

Individusls or organization desiring information ar slotus reports on eicments of the NEPA process should address their inquiries to:

OTten of NEPA Project Amistantz.

Department of Enetgy, 3000

Independence Avenue, SW, Wustingion. DC 2058 .

6. Osersight of Agency NEPA Activities

The Asvisiant Secretary for

Envtronment, Safety and Health or his/ her designee. will be responsible for overail review of DOE NEPA compliance.

\section{Compliance}

These guideiines are intended for use by all persons acting on behalf of DOE in corrying out certain provisions of the CEQ regulations. Any deviation from the guidelines muat be soundly based and must have the advance approval of the Unde: Secretary of DOE.

\section{Rovisions to the Guicieiines}

DOE will, in accordance with to CAR 1507.3. review these guideines on is contimuing bnsis and revise them as necessary to ensure full cotnpliance with the purposes and provisions of NEPA. Substantive changes will be publisined in the Fadeni Regishar and will be finnlly adopted only after an opportunity for puivlic review. 
SECTION D.-TYPKCAL CLASSES OF ACTIONS

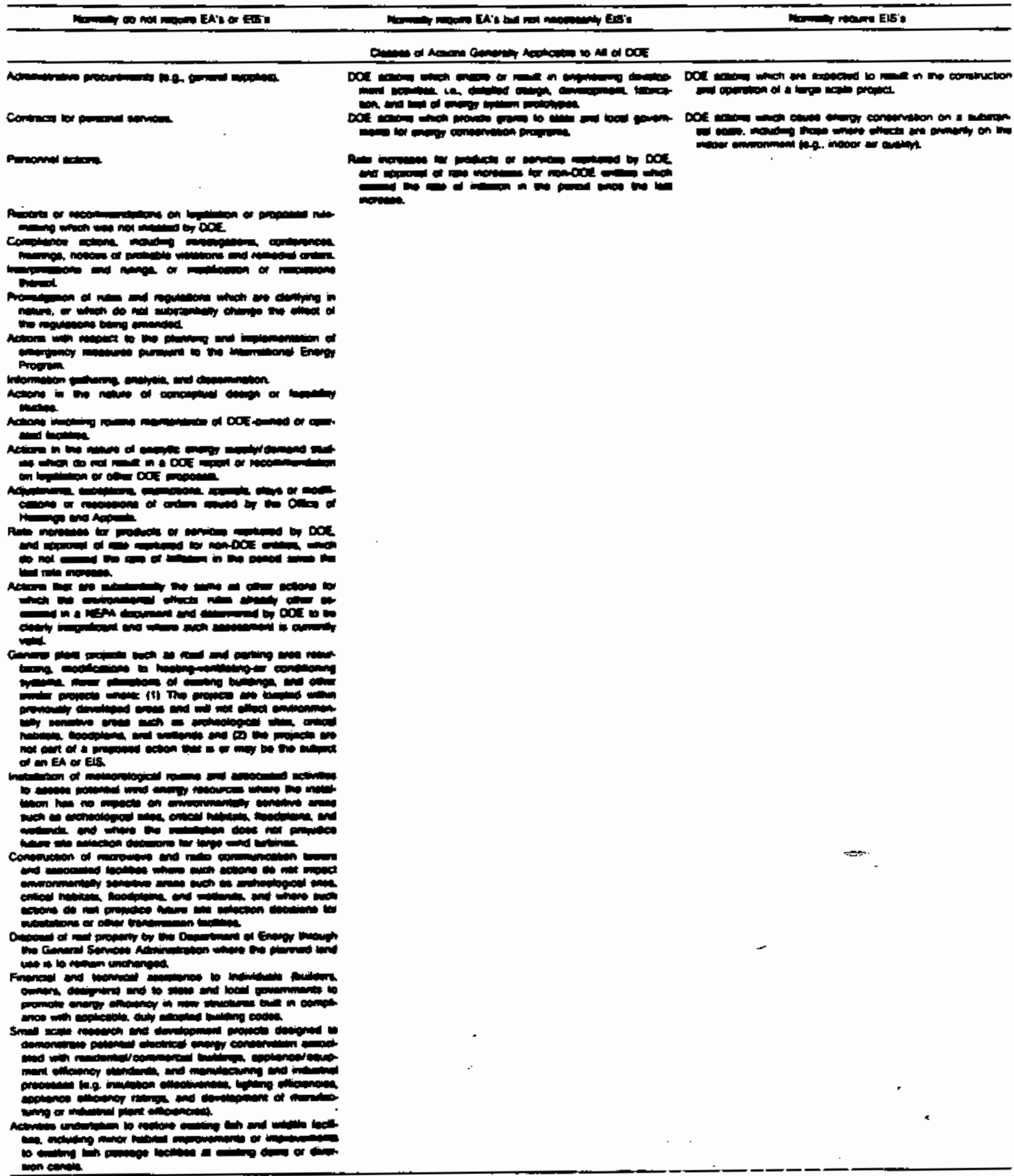

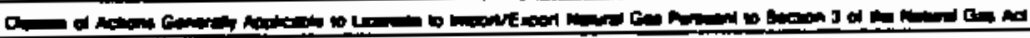

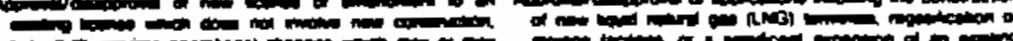
wa

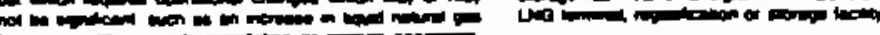




SECTLN D.-TYPICAL CLASSES OF ACTIONS-Continued

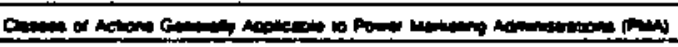

\begin{tabular}{|c|c|c|}
\hline $\min _{\text {man }}$ & & 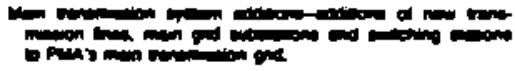 \\
\hline & 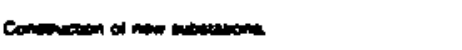 & \\
\hline
\end{tabular}

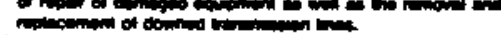

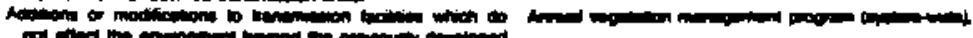

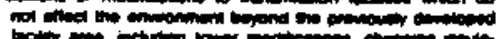

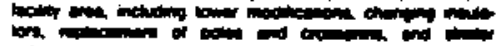

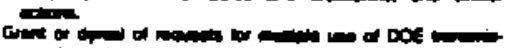

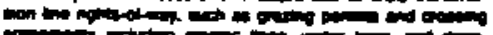

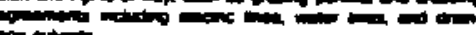

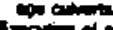

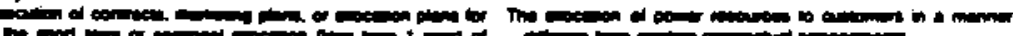

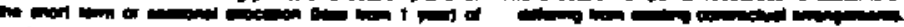

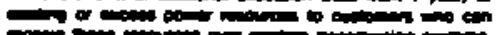

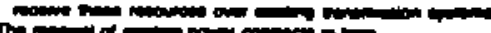

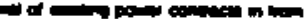

Com a

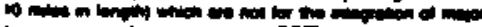

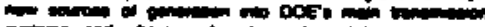

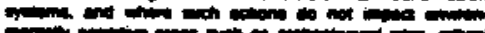

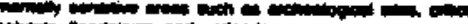

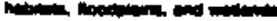

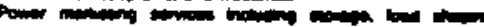

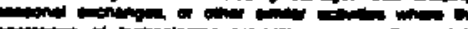

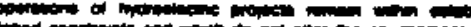
(1)

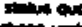

A

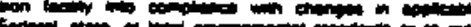
(1)

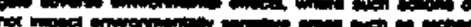
(1)

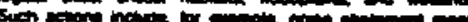

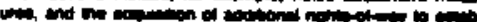

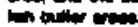

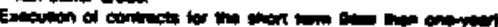

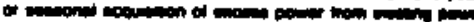

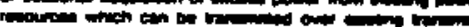

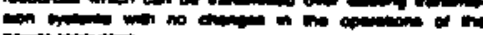
ponem

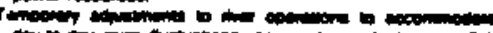

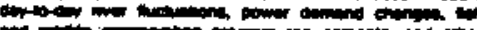

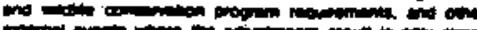

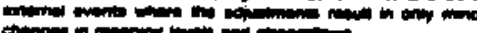

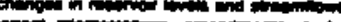

管

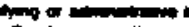

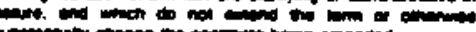

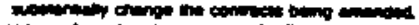

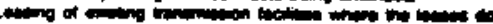

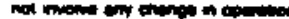

ה

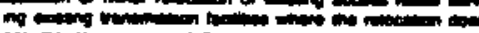

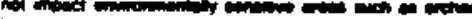

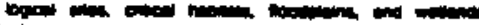

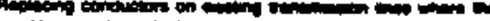

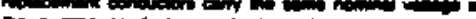
The

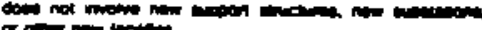
or and nom

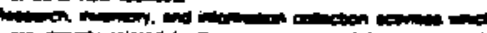

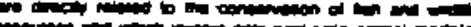

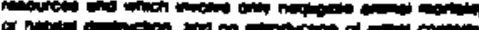

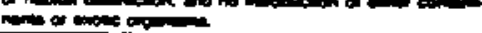

Ca

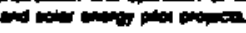

W $\rightarrow$

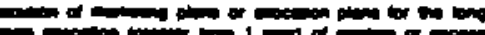

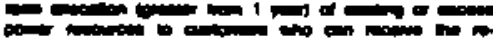

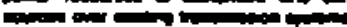




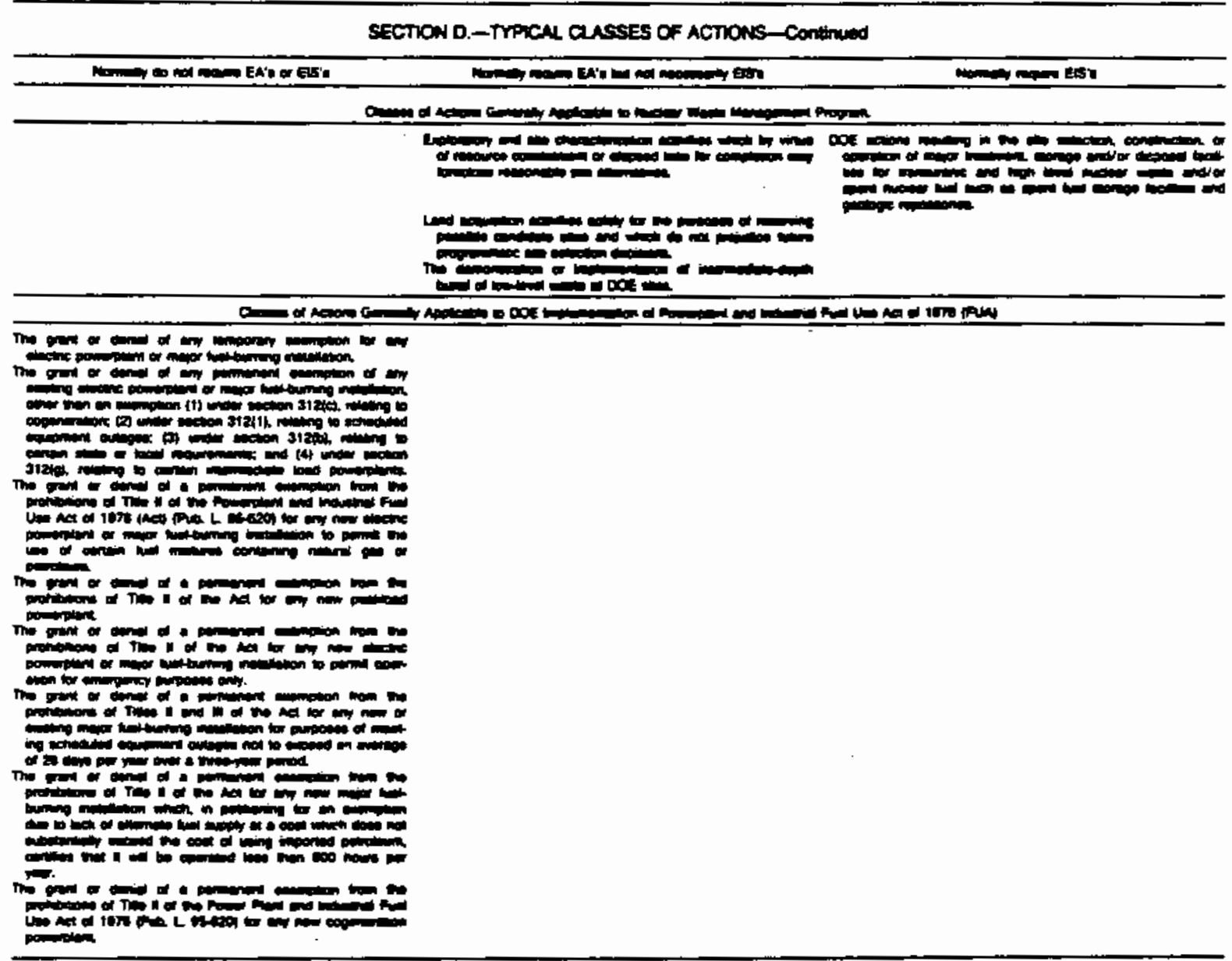

[FR Doc. 67-265e6 Filed 12-14-67; 6:45 em]

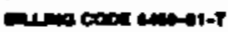




\section{APPENDIX C}

ENVIRONMENTAL EVALUATION CHECKLIST FROM RL ORDER 5440.1A 


\section{ENVIRONMENTAL EVALUATION CHECKLIST}

Potential Environmental Impacts - A detailed explanation of ali "yes" answers is required, and is provided in the text.

1. Air. Will the proposed project/activity:

a. Result in any gaseous discharges to the environment? (If yes, provide description, physical/chemical characterization.)

b. Result in any particulate or droplet releases to the environment?

c. Result in any themal discharges to the atmosphere?

d. Cause any other atmospheric disturbance?

e. Violate any Federal/State or Local emission standards?

f. Be subject to Federal or State standards of performance for new stationary sources? (see WAC 173-400-115)

g. Violate any applicable ambient air quality standards (e.g., CO, hydrocarbons, particulates, $\mathrm{NO}_{2}$, etc.)?

2. Water. Will the proposed project/activity:

a. Result in any liquid discharges to the environment? (If yes, provide description, physical/chemical characterization.)

b. Oischarge heat to surface or subsurface water?

c. Alter stream flow rates? 
d. Significantly alter natural evaporation rates?

e. Release soluble solids to natural waters?

f. Interconnect aquifers?

g. Require installation of wel/s?

h. Require review/permit under the Federal National Pollutant Discharge Elimination System?

i. Require a Corps of Engineers or other permit?

j. Violate any State water quality standards (COD, BOD, TOC, DO, TDS, PH, temperatures, etc.)?

k. Require an $0 i$ or Chemical Spill Control and Prevention Plan?

3. Land Use. Will the project:

a. Conflict with existing zoning or land use?

b. Be located on the 100-year or 500-year floodplain?

c. Be located on wetlands?

d. Generate a volume of solid waste for disposal?
(1) Hazardous?
(2) Radioactive?
(3) Other?

e. Cause erosion?

f. Be located on the Arid Land Ecology Reserve?

9. Conflict with National Environmental Policy Act activities?

h. Impact prime or unique farmland? 
RL $5440.1 \mathrm{~A}$

Attachment I

4. General. Will the proposed project/activity:

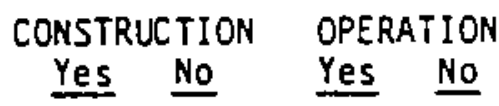

a. Be subject to any other Federal, State or Local environmental regulations not otherwise addressed in this checklist?

b. Increase noise levels?

c. Disturb or alter the ground surface potentially impacting known or undiscovered archeological, historical or Native American religious sites?

d. Require use of carcinogens, pesticides or toxic substances?

e. Impact wildlife or habitat (terrestrial or aquatic)?

f. Affect endangered species or critical habitat?

9. Require long-term commitment of nonrenewable resources?

h. Require new utilities or modifications to existing utilities?

i. Increase off site radiation dose?

j. Impair recreation?

k. Require modifications to the Site-wide Environmentai Surveillance Program? 


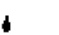

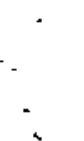

$\checkmark$ 
APPENDIX D

ENVIRONMENTAL CHECKLIST FROM THE STATE ENVIRONMENTAL POLICY ACT REGULATIONS 
PART ELEVEN - FORMS

WAC 197-11-960 Environnental checklist.

ENVIRONMENTAL CHECKLIST

Purpose of Checklist:

The State Environmental Policy Act (SEPA), chapter 43.21C RCW, requires all governmental agencies to consider the environmental impacts of a proposal before making decisions. An environmental impact statement (EIS) must bo prepared for all proposals with probable significant adverse impacts on the quality of the environment. The purpose of this checklist is to provide information to help you and the agency identify impacts from your proposal (and to reduce or avoid impacts from the proposal, if it can be done) and to help the agency decide whether an EIS is required.

Instructions for Applicants:

This environmental checklist asks you to describe some basic information about your proposal. Governmental agencies use this checklist to determine whether the environmental impacts of your proposal are significant, requiring preparation of an EIS. Answer the questions briefly, with the most preciso information known, or give the best description you can.

You must answer question accurately and carefully, to the best of your knowled Be. In most cases, you should be able to answer the questions from your own observations or project plans without the need to hire experts. If you really do not know the answer, or if a question does not apply to your proposal, write "do not know" or "does not apply". Complete answers to the questions now may avoid unnecessary delays later.

Some questions ask about governmental regulations, such as zoning, shoreline, and landmark designations. Answer these questions if you can. If you have problems, the governmental agencies can assist you.

The checklist questions apply to all parts of your proposal, even if you plan to do them over a period of time or on different parcels of land. Attach any additional information that will help 
describe your proposal or its environmental effects. The agency to which you submit this checklist may ask you to expiain your answers or provide additional information reasonably related to determining if there may be significant adverse impact.

Use of checklist for nonproject proposals:

Complete this checklist for nonproject proposals, even though questions may be answered "does not apply." IN ADDITION, coinplete the SUPPLEMENTAL SHEET FOR NONPROJECT ACTIONS (part D).

For nonproject actions, the references in the checklist to the words "project," "applicant," and "property or site" should be read as "proposal," "proposer," and "affected geographic area," respectively.

\section{A. BACKGROUND}

1. Name of proposed project, if applicable:

2. Name of applicant:

3. Address and phone number of applicant and contact person:

4. Date checklist prepared:

5. Agency requesting checklist:

6. Proposed timing or schedule (including phasing, if applicable):

7. Do you have any plans lor future additions, expansion, or further activity related to or connected with this proposal? If yes, explain.

8. List any environmental information you know about that has been prepared, or will be prepared, directly related to this proposal. 
9. Do you know whether applications are pending for governmental approvals of other proposals directly affecting the property covered by your proposal? If yes, explain.

10. List any government approvals or permits that will be noeded for your proposal, if known.

11. Give brief, complete description of your proposal, including the proposod uses and the size of the project and sito. There are several questions later in this checklist that ask you to describe certain aspects of your proposal. You do not need to repeat those answers on this page. (Lead agencies may modify this form to include additional specific information on project description.)

12. Location of the proposal. Give sufficiont information for a person to understand the precise location of your proposed project, including a street addreas, if any, and section, township, and range, if known. If a proposal would oceur over a range of area, provide the range or boundaries of the site(g). Provide a legal description, site plan, vicinity map, and topographic map, if reasonably avilable. While you should submit any plans required by the agency, you are not required to duplicate maps or detailed plans submitted with any permit applications related to this checklist. 
Appendix C

TO BE COMPLETED BY APPLCANT

EVALUATION FOR

AGENCY USE ONLY

\section{B. ENVIRONMENTAL ELEMENTS}

1. Earth

a. General description of the site (circle one): Flat, rolling, hilly, steep slopes, mountminous, other

b. What is the steepest slope on the site (npproximate percent slope)?

c. What general types of soils are found on the site (for example, clay, sand, gravel, peat, muck)? If you know the classification of agricultural soils, specify them and note any prime farmiand.

d. Are there surface indications or history of unstable soils in the immediate vicinity? If so, describe.

e. Describe the purpose, type, and approximate quantities of any filling or grading proposed. Indicate source of fill.

C. Could erosion occur as a result of clearing, construction, or use? If so, generally describe.

B. About what percent of the site will be covered with impervious surfaces after project construction (for example, asphalt or buildings)?

h. Proposed measures to reduce or control erosion, or other impacts to the earth, if any. 
2. Air

a. What types of emissions to the air would result from the proposal (i.e., dust, automobile, odors, industrial wood smoke) during construction and when the project is completed? If any, generally describe and give approximate quantities if known.

b. Are there any off-site sources of emissions or odor that may affect your proposal? If so, generally describe.

c. Proposed measures to reduce or control emissions or other impacts to air, if any:

3. Water

a. Surface:

1) Is there any surface water body on or in the immediate vicinity of the site (including yearround and seasonal streams, saltwater, lakes, ponds, wetlands)? If yes, describe type and provide names. If appropriate, state what stream or river it flows into.

2) Will the project require any work over, in, or adjacent to (within 200 foet) the described waters? If yes, please describe and attach available plans.

3) Estimate the amount of fill and dredge material that would be placed in or removed from surface water or wetlands and indicate the erea of 
Appendix $C$

TO BE COMPLETED BY APPLICANT

EVALUATION POR

AGENCY USE ONLY

the site that would be affected. Indicate the source of fill material.

4) Will the proposal require surface water withdrawals or diversions? Give general description, purpose, and approximate quantities if known.

5) Does the proposal lie within a 100-year floodplain? If so, note location on the site plan.

6) Does the proposal involve any discharges of waste materials to surface waters? If so, describe the type of waste and anticipated volume of discharge.

b. Ground:

1) Will ground water be withdrawn, or will water be discharged to ground water? Give general description, purpose, and approximate quantities if known.

2. Describe waste material that will be discharged into the ground from septic tanks or other sources, if any (for example: Domestic scwage; industrial, containing the following chemicals ...; agricultural; etc.). Describe the general size of the system, the number of such systems, the number of houses to be served (if applicable), or the number of animals or humans the system(s) are expected to serve. 
c. Water Runoff (including storm water):

1) Describe the source of runoff (including storm water) and method of collection and disposal, if any (include quantities, if known). Where will this water flow? Will this water flow into other waters? If so, describe.

2) Could waste materials enter ground or surface waters? If so, generally describe.

d. Proposed measures to reduce or control surface, ground, and runoff water impacts, if any:

\section{Plants}

a. Check or circle types of vegetation found on the site:

deciduous tree: alder, maple, aspen, other evergreen tree: fir, cedar, pine, other shrubs

Brass

pasture

crop or grain

wet soil plants cattail, buttercup, bullrush, skunk cabbage, other water plants: water lily, eelgras, milfoil, other other types of vegetation

b. What kind and amount of vegetation will be removed or altered?

c. List threatened or endangered species known to be on or near the site.

d. Proposed landscaping, use of nativo plants, or 
Appendix C

TO BE COMPLETED BY APPLICANT

EVALUATION FOR

AGENCY USE ONLY

other measures to preserve or enhance vegetation on the site, if any:

\section{Animals}

a. Circle any birds and animals which have been ouserved on or near the site or are known to be on or near the site:

birds: hawk, heron, eagle, songbirds, other. ....................................

mammals: deer, bear, elk, beaver, other:

fish: bass, salmon, trout, herring, shellfish, other.

b. List any threatened or endangered species known to be on or near the site.

c. Is the site part of a migration route? If so, explain.

d. Proposed measures to preserve or enhance wildlife, if any:

\section{Energy and Natural Recources}

a. What kinds of energy (electric, natural ges, oil, wood stove, solar) will be used to meet the completed project's energy needs? Describe whether it will be used for heating, manufacturing, etc.

b. Would your project affect the potential use of solar energy by adjacent properties? If so, generally describe. 
c. What kinds of energy conservation features are included in the plans of this proposal? List other proposed measures to reduce or control energy impacts, if any.

\section{Environmental Health}

a. Are there any environmental health hemards, including exposure to toxic chemicals, risk of fire and explosion, spill, or hamerdous watto, that could occur as a result of this proposal? If so, describe.

1) Describe special emergency services that might be required.

2) Proposed measures to reduce or control environmental health hemards, if any.

\section{b. Nolse}

1) What types of noise exist in the aren which may affect your project (for examplex traffic, equipment, operation, other)?

2) What types and lovels of noise would be created by or associatod with the project on a short-term or a long-term basis (for examples traffic, construction, operation, other)? Indicate what hours noise would come from the site.

3) Proposed measures to reduce or control noise impacts, if any. 
Appendix $C$

TO BE COMPLETED BY APPLCANT

EVALUATION TOR

AGENCY USE ONLY

\section{Land and Shoreline Use}

a. What is the current use of the site and adjacent properties?

b. Has the site been used for agriculture? If $s$, describe.

c. Describe any structures on the site.

d. Will any structures be demolished? If so, what?

e. What is the current zoning classification of the site?

f. What is the current comprehensive plan designation of the site?

8. If applicable, what is the curront shoreline master program designation of the site?

h. Has any part of the site been clessified as an "environmentally sensitive" area? If so, specify.

i. Approximately how many people would reside or work in the completed project?

j. Approximately how many people would the completed project displace? 
k. Proposed measures to avoid or reduce displacement impacts, if any:

1. Proposed measures to ensure the proposal is compatible with existing and project land uses and plans, if any:

\section{Housing}

a. Approximately how many units would bo provided, if any? Indicate whether high, middle, or low-income housing.

b. Approximately how many units, if any, would be eliminated? Indicate whether high, middle, or low-income housing.

c. Proposed measures to reduce or control housing impacts, if any:

\section{Aesthetles}

a. What is the tallest height of any proposed structure(s), not including antennas; what is the principal exterior building material(s) proposed?

b. What views in the immediate vicinity would bo altered or obstructed?

c. Proposed measures to reduce or control aesthetic impacts, if any: 
Appendix $C$

TO BE COMPLETED BY APPLICANT

EVALUATION FOR AGENCY USE ONLY

\section{Light and Glare}

a. What type of light or glare will the proposal produce? What time of day would it mainly occur?

b. Could light or glare from the finished project be a safety hazard or interfere with views?

c. What existing off-site sources of light or glare may affect your proposal?

d. Proposed measures to reduce or control light and Blare impacts, if any:

\section{Recreation}

a. What designated and informal recreational opportunities are in the immediate vicinity?

b. Would the proposed project displace any existing recreational uses? If so, describe.

c. Proposed measures to reduce or control impacts on recreation, including recreation opportunities to be provided by the project or applicant, if any.

\section{Historic and Cultural Preservation}

a. Are there any places or objects listed on, or proposed for, national, state, or local preservation registers known to be on or next to the site? If 20 , generally describe. 
b. Generally describe any landmarks or evidence of historic, archacological, scientific, or cultural importance known to be on or next to the site.

c. Proposed measures to reduce or control impacts, if any:

\section{Transportacios}

a. Identify public streets and highways serving the site, and describo proposed access to the existing street system. Show on site plans, if any.

b. Is site currently served by public transit? If not, what is the approximate distance to the nearest transit stop?

c. How many parking spaces would the completed project have? How many would the project eliminate?

d. Will the proposal require any new raads or streets, or improvements to existing roads or streets, not including driveways? If $s_{0}$, generally describe (indicate whether public or private).

e. Will the project use (or oceur in the immediate vicinity of water, rail, or air transportation? If so, generally describe.

f. How many vehicular trips per day would be generated by the completed project? If known, indicate when peak volumes would occur. 
Appendix $C$

TO BE COMPLETED BY APPLICANT

EVALUATTON FOR

AGENCY USE ONLY

8. Proposed measures to reduce or control transportation impects, if any:

\section{Public Services}

a. Would the project result in an increased need for public services (for example: fire protection, police protection, health care, schools, other)? If so, generally describe.

b. Proposed measures to reduce or control direct impacts on public services, if any.

\section{Utilities}

a. Circle utilities currently available at the site: electricity, natural gas, water, refuse service, telephone, sanitary sewer, septic system, other.

b. Describe the utilities that are proposed for the project, the utility providing the service, and the general construction activities on the site or in the immediate vicinity which might be needed.

\section{SIGNATURE}

The above answers are true and complete to the best of my knowledge. I understand that the lead agency is relying on them to make its decision.

Signature:

Date Submitted: 


\section{SUPPLEMENTAL SHEET FOR NONPRO- JECT ACTIONS}

(do not use this sheet for project actions)

Because these questions are very general, it may be helpf ul to read them in conjunction with the list of the elements of the environment.

When answering these questions, be aware of the extent the proposal, or the types of activities likely to result from the proposal, would affect the item at a greater intensity or at a faster rate than if the proposal were not implemented. Respond briefly and in genoral terms.

1. How would the proposal be likely to increase discharge to water; emissions to air, production, storage, or release of toxic or hazardous substances; or production of noise?

Proposed measures to avoid or reduce such increases are:

2. How would the proposal be likely to affect plants, animais, fish, or marine life?

Proposed measures to protect or conserve plants, animals, fish, or marine lifo are:

3. How would the proposal be likely to deplete energy or natural resources?

Proposed measures to protect or conserve energy and natural resources are: 
Appendix $C$

TO BE COMPLETED BY APPLUCANT

EVALUATION FOR

AGENCY USE ONLY

4. How would the proposal be likely to use or affect environmentally sensitive areas or areas designated (or eligible or under study) for governmental protection; such as parks, wilderness, wild and scenic rivers, threatened or endangered species habitat, historic or cultural sites, wetlands, floodplains, or prime farmlands?

Proposed measures to protect such resources or to avoid or reduce impacts are:

5. How would the proposal be likely to affect land and shoreline use, including whether it would allow or encourage land or shoreline uses incompatible with existing plans?

Proposed measures to avoid or reduce shoreline and land use impacts are.

6. How would the proposal be likely to increase demands on transportation or public services and utilities?

Proposed measures to reduce or respond to such demand(s) are:

7. Identify, if possible, whether the proposal may conflict with local, state, or federal laws or requirements for the protection of the environment. 


\section{DISTRIBUTION}

No. of

Copies

OFFSITE

10 DOE/Office of Scientific and Technical Information

C. M. Borgstrom

Office of NEPA Project

Assistance, EH-25

U.S. Department of Energy

Washington, DC 20545

J. C. Tseng

Office of Environmental

Guidance and Compliance, EH-23

U.S. Department of Energy

Washington, DC 20545

R. L. Hames

Davis Wright \& Jones

1501 4th Ave

2600 Century Square

Seattle, WA 98101

\section{ONSITE}

29 DOE Richland Operations Office

M. J. Anthony

E. A. Bracken

R. M. Carosino

C. R. Delannoy

P. F. Dunigan (10)

0 . A. Farabee

R. D. Freeberg

R. E. Gerton

J. D. Goodenough

R. G. Hastings

R. A. Holten

J. R. Hunter

R. D. Izatt

M. S. Karol

J. J. Keating

A. J. Rizzo

D. M. Smith
No. of

Copies
J. J. Sutey
M. W. Tiernan
L. C. Williams

6 Westinghouse Hanford Company

D. B. Carter

C. Defigh-Price

C. J. Geier

M. T. Jansky

R. E. Lerch

H. E. McGuire

Kaiser Engineering Hanford

W. H. Bodily

Hanford Environmental Health Foundation

L. J. Mass

70 Pacific Northwest Laboratory

R. C. Adams

H. J. Bair

R. W. Bienert

T. D. Chikalla

J. M. Davidson

J. H. Falco

C. A. Geffen (10)

M. S. Hanson

D. G. Huizenga

M. H. Killinger (5)

S. E. King (10)

J. F. Keller

P. J. Mellinger

E. B. Moore

K. S. Murthy

I. C. Nelson

J. V. Robinson

K. B. Selby

A. K. Stalker (10)

S. L. Stein

G. M. Stokes 
No. of

Copies

J. L. Straasiund

B. R. Stults

W. L. Templeton (10)

Publishing Coordination

Technical Report Files (5) 